\title{
Relationships Between Aerodynamic Roughness and Land Use and Land Cover in Baltimore, Maryland
}

GEOLOGICAL SURVEY PROFESSIONAL PAPER 1099-C 



\section{Relationships Between Aerodynamic Roughness and Land Use and Land Cover in Baltimore, Maryland}

By FRANGIS W. NICHOLAS and JOHN E. LEWIS, JR.

THE INFLUENCES OF LAND USE AND LAND

COVER IN CLIMATE ANALYSIS

GEOLOGICAL SURVEY PROFESSIONAL PAPER 1099-C

An example of environmental analysis using

land use and land cover information

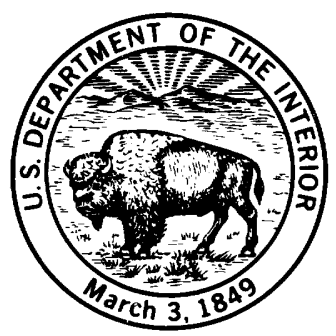

UNITED STATES GOVERNMENT PRINTING OFFICE, WASHINGTON $: 1980$ 
UNITED STATES DEPARTMENT OF THE INTERIOR

CECIL D. ANDRUS, Secretary

\section{GEOLOGICAL SURVEY}

H. William Menard, Director

Library of Congress Cataloging in Publication Data

Nicholas, Francis W

Relationships between aerodynamic roughness and land use and land cover in Baltimore, Maryland.

(Geological Survey professional paper ; 1099-C)

Bibliography: p.

1. Baltimore-Climate. 2. Land use-Maryland-Baltimore. 3. Aerodynamics. I. Lewis, John E., 1937— joint author. II. Title. III. Series: United States. Geological Survey. Professional paper; 1099-C.

QC981.7.U7N53 $\quad 551.6 \quad 79-600213$

For sale by the Superintendent of Documents, U.S. Government Printing Office Washington, D.C. 20402

Stock Number 024-001-03286-4 


\section{CONTENTS}

Abstract

Introduction

Parameters in urban climatology

Roughness length

Surface roughness in urban environments

Roughness length estimates from surface descriptions Calculation of surface roughness for Baltimore, $\mathrm{Md}$.-

The study area

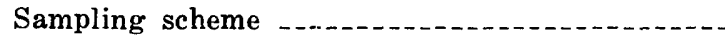

Pilot study for acquisition of dimensional data ..

Testing the effects of wind variations on building

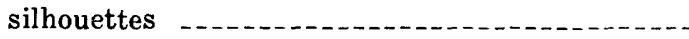

Modifications and processing of dimensional data Basic data description

Descriptions of land use and land cover classification systems

USGS Level II system _.........................

Baltimore Zoning Ordinance system .............

Baltimore Level III system

Page
C1
1
2
3
5
5
6
6
6
8

11
14
15

16
17
19
20

C1

2
Spatial distribution of surface roughness in the study area -

Statistical association between land use and land cover and aerodynamic roughness

USGS Level II system

Baltimore Zoning Ordinance system ............

Baltimore Level III system _......................

The CBD as a unique land use and land cover class Land use and land cover classes ranked by mean roughness lengths

Evaluation of aerodynamic roughness by simulation modeling of the surface climate .................... Sensitivity testing Simulation of Baltimore Level III system values.Simulation of CBD values ........................ Applications of land use and land cover information in urban climatology

References cited

Page $\mathrm{C} 20$

21

24

25

25

26

28

29

30

30

31

32

34

\section{ILLUSTRATIONS}

Figure 1. Diagram showing characteristics of atmospheric flow layers in the lower

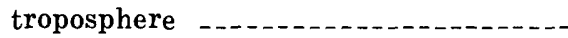

2. Graphical determination of roughness length -

3. Baltimore city land use and land cover map with study area delimited ......

4. Isometric drawing of the Druid Hill test plot

5. Sanborn map of the Druid Hill test plot-

6. Diagram showing effects of wind direction on surface roughness

7. Histogram of coefficients of variation for data from plot rotation

8. Histogram of 324 surface roughness

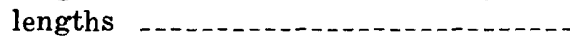

9. Land use and land cover map of Baltimore, based on USGS Level II classification system
Page
C3
4
7
8
10
12
13
16
18

Figure 10. Histogram and map showing surface roughness in the Baltimore study area

11. Diagram showing distribution of surface roughness in the Baltimore area .....

12. Diagram showing land use and land cover classes ranked by mean values of surface roughness

13. Graph showing surface temperature as a function of surface roughness

14. Map showing contours on surface roughness in Baltimore, Md., simulated from USGS Level II land use and land cover data

33

15. Map showing contours on surface roughness in Baltimore, Md., simulated from Baltimore Level III land use and land cover data 


\section{TABLES}

TABLE 1. Roughness lengths, $z_{0}$, determined at urban sites

2. Effects of seasonal changes in vegetation on roughness length, by land use and land cover type, Sacramento, Calif. --

3. Druid Hill test plot dimensional worksheet -

4. Relation between roughness length and

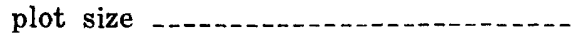

5. Number and percent of sample plots, by type of cover and surface roughness formula used

6. Drag coefficients for different numbers of tree rows and tree heights

7. Roughness lengths assigned to open areas

8. Procedures for organizing surface description data

9. Summary of roughness length data

10. Land use and land cover in Baltimore according to three different classification

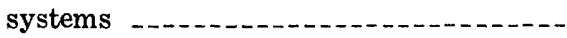

11. Land use and land cover in selected cities

12. USGS Level II land use and land cover classes applicable to this study -..---

12a. USGS Level II classes used in this study and their roughness lengths ........

13. Baltimore Zoning Ordinance classes according to gross building densities -.-

14. Baltimore Level III land use and land cover classes and their roughness lengths system
TABLE 15. Statistical techniques used in land use and land cover analysis

16. Comparison of the variance ratio for three land use and land cover systems

17. Differences between the paired means of roughness lengths of USGS Level II land use and land cover classes ....-

18. Differences between the paired means of roughness lengths of Baltimore Zoning Ordinance classes -...-

19. Differences between the paired means of roughness lengths of Baltimore Level III land use and land cover classes -.

20. Aerodynamic roughness characteristics of the Baltimore CBD

21. Input data (boundary conditions) for the numerical simulation experiment -..--

22. Output data from numerical simulation model

Page

C21

23. Values of the energy balance components simulated for Baltimore

24. Values of the energy balance components simulated for the Baltimore CBD -...-

25. Roughness lengths summarized for USGS Level II land use and land cover classes

26. Roughness lengths summarized for Baltimore Level III land use and land cover classes and the CBD

27. Some recent climatological models using roughness length _....................

SYMBOLS USED IN TEXT

\begin{tabular}{|c|c|c|c|}
\hline Symbol & Definition & Symbol & Definition \\
\hline $\begin{array}{l}a \\
b\end{array}$ & $\begin{array}{l}\text { Empirical constant of }-1.24 \\
\text { Empirical constant of } 1.19\end{array}$ & $E$ & $\begin{array}{l}\text { Test statistic for one-way analysis of variance } \\
\text { (variance ratio) }\end{array}$ \\
\hline$d$ & $\begin{array}{l}\text { Zero-plane displacement, assumed to be near } \\
\text { roof top level in urban environments }\end{array}$ & $F$ & $\begin{array}{l}\text { Test statistic for one way analysis of variance } \\
\text { (difference between the class means) }\end{array}$ \\
\hline $\begin{array}{l}h \\
h^{*}\end{array}$ & $\begin{array}{l}\text { Average crop height } \\
\text { Average height of obstacles }\end{array}$ & $\begin{array}{l}H \\
H_{k w}\end{array}$ & $\begin{array}{l}\text { Sensible heat flux } \\
\text { Test statistic for Kruskal-Wallis one-way anal- } \\
\text { ysis of variance }\end{array}$ \\
\hline$k$ & $\begin{array}{l}\text { Von Karman constant, a constant of proportion- } \\
\text { ality approximately equal to } 0.42\end{array}$ & $L$ & Latent heat flux \\
\hline$s$ & Standard deviation & $\frac{N}{N}$ & $\begin{array}{l}\text { Number of roughness elements on a lot } \\
\text { Average number of observations }\end{array}$ \\
\hline $\begin{array}{l}s^{2} \\
t\end{array}$ & $\begin{array}{l}\text { Variance estimate } \\
\text { Tangential shearing stress }\end{array}$ & $Q$ & $\begin{array}{l}\text { "Studentized Range" for a given significance } \\
\text { level }\end{array}$ \\
\hline $\bar{u}(z)$ & Steady mean wind flow at height $z$ & $\boldsymbol{R}_{n}$ & Sum of net radiation \\
\hline$v^{*}$ & $\begin{array}{l}\text { Shear stress, or friction velocity, defined as the } \\
\text { square root of } t / p\end{array}$ & $\begin{array}{l}S \\
S_{1}\end{array}$ & $\begin{array}{l}\text { Soil heat flux } \\
\text { Silhouette area of an average obstacle }\end{array}$ \\
\hline$z$ & Height at which wind speed is measured & $S_{2}$ & Specific area, $\mathbf{A} / \mathrm{N}$ \\
\hline$z_{0}$ & Roughness length & $T$ & Temperature, in degrees Celsius \\
\hline $\boldsymbol{A}$ & Lot area & $\bar{X}$ & Mean value \\
\hline$D$ & Test statistic for Q-method & $\rho$ & Air density \\
\hline
\end{tabular}




\title{
RELATIONSHIPS BETWEEN AERODYNAMIC ROUGHNESS AND LAND USE AND LAND COVER IN BALTIMORE, MARYLAND ${ }^{1}$
}

\author{
By FRANCIS W. NICHOLAS ${ }^{2}$ and JOHN E. LEWIS, JR. ${ }^{3}$
}

\begin{abstract}
Urbanization changes the radiative, thermal, hydrologic, and aerodynamic properties of the Earth's surface. Knowledge of these surface characteristics, therefore, is essential to urban climate analysis. Aerodynamic or surface roughness of urban areas is not well documented, however, because of practical constraints in measuring the wind profile in the presence of large buildings. Using an empirical method designed by Lettau, and an analysis of variance of surface roughness values calculated for 324 samples averaging 0.8 hectare (ha) of land use and land cover sample in Baltimore, Md., a strong statistical relation was found between aerodynamic roughness and urban land use and land cover types. Assessment of three land use and land cover systems indicates that some of these types have significantly different surface roughness characteristics. The tests further indicate that statistically significant differences exist in estimated surface roughness values when categories (classes) from different land use and land cover classification systems are used as surrogates. A Level III extension of the U.S. Geological Survey Level II land use and land cover classification system provided the most reliable results. An evaluation of the physical association between the aerodynamic properties of land use and land cover and the surface climate by numerical simulation of the surface energy balance indicates that changes in surface roughness within the range of values typical of the Level III categories induce important changes in the surface climate.
\end{abstract}

\section{INTRODUCTION}

The climatic changes accompanying urbanization are recognized as responses to new aerodynamic, thermal, radiative, and hydrologic properties of the local surface. The urban climate is therefore a product of surface-induced changes to the components of the mass and energy balance, especially

\footnotetext{
1 The research reported herein was funded in part by the National Aeronautics and Space Administration and U.S. Geological Survey as one phase of the Central Atlantic Regional Ecological Test Site (CARETS) Project.

2 Francis W. Nicholas, deceased. After serving with the U.S. Geological Survey, he joined the faculty of Mankato State University in Minnesota.

${ }^{3}$ John E. Lewis is now with McGill University, Montreal, Quebec.
}

the soil, air, and latent heat transfers. Current research in urban climatology attempts to improve on solutions to the energy balance problem. In the application of numerical simulation modeling to the surface energy balance, the accurate qualification of crucial urban surface parameters such as albedo, thermal capacity and conductivity, aerodynamic (surface) roughness, and evaporation remains problematic.

This paper evaluates the areal quantification of surface roughness, the parameter important for its role in the turbulent transfer of heat, water, and atmospheric pollutants. The observational data needed for specifying and quantifying urban surface parameters is scaree and costly. Moreover, it is difficult to represent large, complex areas by necessarily limited sampling. In this study the areal quantification is achieved by a statistical characterization of building geometry in land use and land cover regions in Baltimore, Md. Roughness values are calculated from 324 microsamples averaging 0.8 ha by the use of building geometry and density description fitted to an empirical formula. Land use and land cover information thus becomes a surrogate or function of building density and geometry from which the surface roughness values are subsequently determined.

A specific methodology for acquiring the roughness data includes a capability for measuring roughness changes induced by varying wind directions on typical building geometries. Three land use and land cover classification systems are assessed for their ability to differentiate values of surface roughness. In addition, surface roughness is evaluated by numerical simulation modeling for its influence on the surface energy balance. 


\section{PARAMETERS IN URBAN CLIMATOLOGY}

With urbanization significant climatic changes occur. Urban structures, impervious surface materials, and emissions of heat and aerosols create changes to mass and energy balances at the surface. Aerosols change the net radiation balance, reduce visibility, create health hazards, and alter precipitation processes. The large thermal admittance from typical urban surface materials adds to the contribution of sensible heat in the urban atmosphere by such activities as heating, transportation, and industry. Urban surface materials also inhibit infiltration of precipitation while reducing the evapotranspiration opportunity by rapidly channeling runoff into storm sewers. Taller and more densely constructed buildings reduce the albedo, slow the mean wind, and channel low-level winds. Buildings also induce turbulence by increasing the frictional drag. Turbulence is the mechanism that transports mass, momentum, and energy through the lowest parts of the atmosphere. This concern with surface influences has, therefore, made urban climatology a distinctive part of microclimatology.

Problems in urban climatology, because of the areal extent of the city, often involve the use of space and time scales beyond the traditional limits of microclimatology. Vertical dimensions of buildings sometimes exceed the lower 100 meters $(\mathrm{m})$ of the atmosphere defined by Munn (1966) as the surface boundary layer. The traditional space scale of 1 square kilometer $\left(\mathrm{km}^{2}\right)$ or less used to define the microscale regime is obviously exceeded in every metropolitan area. Thus, the investigation of some urban climatology problems crosses into the mesoscale realm, although individual sites may retain a microscale definition. Each city is a mosaic of microclimates and the scope of any investigation is set by the scale of its total problem.

Recognition of the parameters of the physical environment is fundamental to understanding the processes of the urban climate. Like any local climate, urban climate is understood as a response to differing surface exchanges of mass, momentum, and energy.

The concept of climatonomy introduced by Lettau demonstrates the usefulness of parameterizing the physical environment (Lettau and Lettau, 1969; Lettau and Lettau, 1974). Climatonomy, sometimes called synthetic climatology, concerns the functional relationship between solar, meteorological, and geographical variables. These relationships, called process-response functions, are used to determine the magnitude of response to a given set of input conditions. Climatonomical parameterization therefore, provides the approach needed to understanding the urban atmosphere in order to assess the implications of surface modification. This assessment is essentially the objective of simulation modeling.

Interaction between the surface and its overlying atmosphere involves the partitioning of available energy by competing processes. The replacement of soil and vegetation with impervious materials during urban growth reduces the latent heat flux into the atmosphere by lowering evapotranspiration. During the day when insolation creates a large vertical temperature gradient across the earth-atmosphere interface, urban surface materials possessing higher heat capacities and conductivities increase the molecular heat flux downward. During the night when insolation is absent the higher thermal storage capacity of these urban surface materials contributes to the nocturnal heating of the overlying air. The direction of the sensible heat flux is then toward the surface.

Aerodynamic roughness, induced by the complex three-dimensional surface geometry, affects the degree of turbulent transfer of latent and sensible heat into the overlying atmosphere. Furthermore, the molecular heat flux into the subsurface is coupled to the effects of more latent and sensible heat transfer into the atmosphere. The surface climate is therefore the result of an interacting set of process-response functions.

Simplified numerical simulation models of the surface climate such as those by Myrup (1969), Outcalt (1972a), and Pandolfo and others (1971) provide research tools for evaluating the energy balance response to hypothetical and actual surface changes. For energy balance simulation, Outcalt (1972a) identifies three groups of variables that create the climatic environment: temporal, meteorological, and geographic. Temporal data determine the solar function for diurnal and seasonal energy regimes. The meteorological data specify atmospheric conditions that may enhance or reduce the surface energy gradients. Geographic variables specify the physical parameters of the surface environment.

Improvement of solutions to the surface energy balance remains problematic because many of the geographic, or surface, parameters such as soil heat diffusivity, albedo, evaporation area, and surface roughness are only crudely known. Careful point sampling may be accurate at the microscale while only poorly representing the region (Myrup and Morgan, 1972). These long-standing problems have 
been described in climatological research reviews during the past century (Landsberg, 1957).

Recent advances in remote sensing technology, however, suggest a powerful tool that may overcome the classic problem of describing and quantifying regional models. Myrup (1969) states "information on the physical nature of cities, such as the average thermal properties or total green area and roughness length of cities is hard to come by. It would seem that the gathering of such information would be an excellent objective for remote sensing technology . ..." In response to this problem, research objectives increasingly list land use and land cover description by remote sensing as a means of quantifying the spatial distribution of surface properties. "One objective is to demonstrate the relationship between land use and microclimate, as part of a GAP/CARETS program effort to develop land use information systems, with implications for the determination of the environmental impact of land use changes ..." (Alexander and Lewis, 1972). In discussing the urban biosphere and the importance of surface structure to energy exchanges in the surface climate, Landsberg (1973) states that "the many micrometeorological surveys of cities that have been published over the last four decades leave no doubt that land use is at the root of the modifications which have biological effects. ..." The present study is principally concerned with surface roughness and its areal quantification based on land use and land cover information derived from three different classification systems.

\section{ROUGHNESS LENGTH}

Roughness length is defined as the height above the surface at which the horizontal component of the wind speed approaches zero, measured logarithmically downward from the gradient wind level where the free flowing winds are an energy source free of surface influences. Roughness length is thus some fraction of the thickness of the obstructed surface boundary layer in the lower troposphere (fig. 1).

Below the gradient wind level in the lower troposphere is the planetary boundary layer or region where the atmospheric flow is directly influenced by the nature of the surface. The outer part of the boundary layer, known as the Ekman spiral layer, is characterized by winds that change in direction and speed as height above the surface decreases in reaction to increasing shear stress and increasing frictional drag. Energy transmitted downward through the spiral layer interacts directly with the underlying terrain, and the momentum flux toward the surface varies with the roughness of the surface.

Roughness length is calculated on the basis of boundary layer theory. The vertical distribution of wind speed is a function of both surface roughness and the stability of the atmosphere. The following empirically determined equations describe a logarithmic wind profile close to the surface in a neutrally stratified atmosphere (Slade, 1968). The gradient of the wind profile is

$$
\frac{d \bar{u}(z)}{d z}=\frac{v^{*}}{k z}
$$

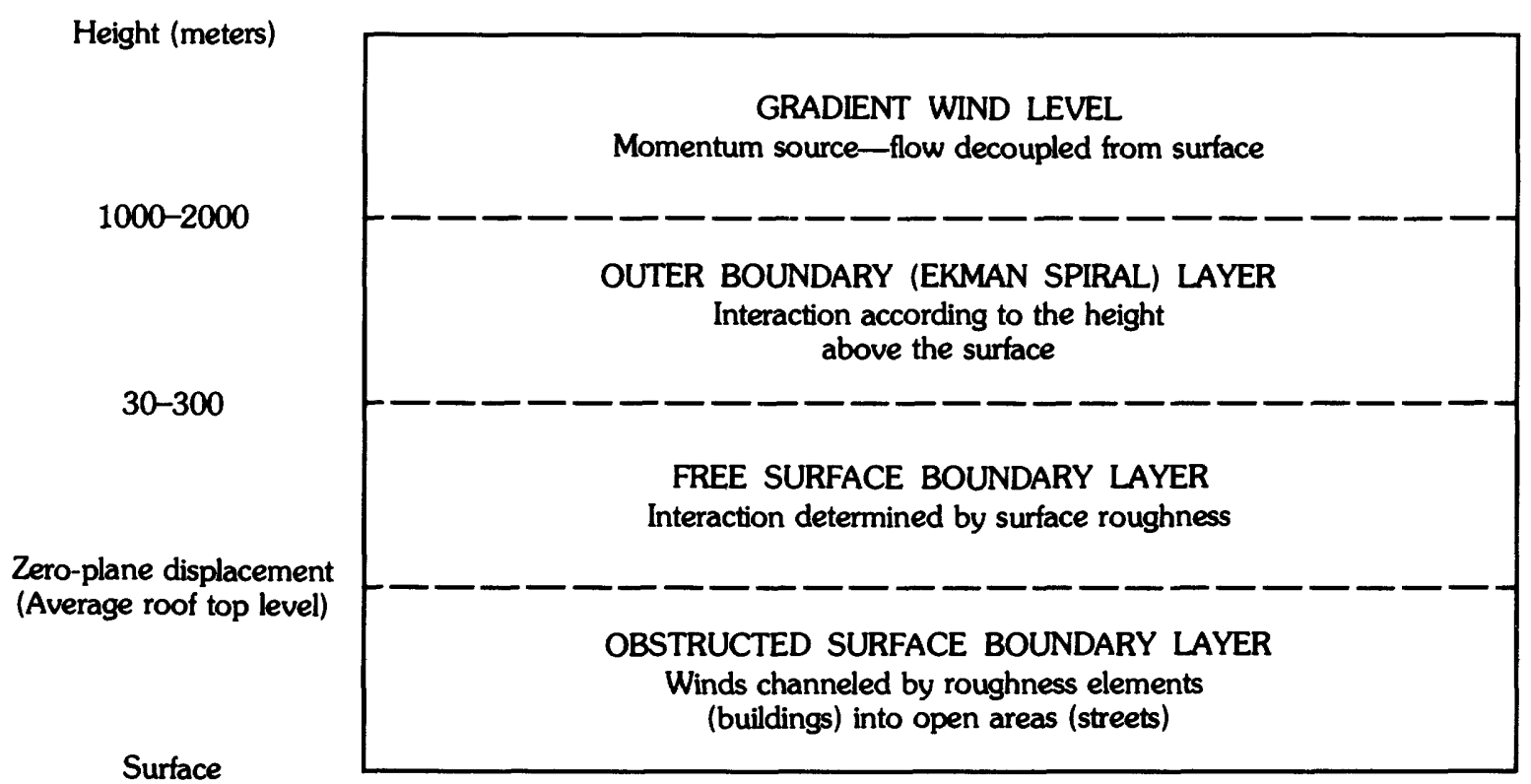

Figure 1.-Characteristics of atmospheric flow layers in the lower troposphere. 
The integrated wind profile is

$$
\bar{u}(z)=\frac{v^{*}}{k} \ln \frac{z}{z_{o}} .
$$

The integrated wind profile modified to allow for the displacement by roughness elements is

where

$$
\bar{u}(z)=\frac{v^{*}}{k} \ln \frac{z-d}{z_{o}},
$$

$\bar{u}(z)$ is the steady mean wind flow at height $z$;

$v^{*}$ is the shear stress, or friction velocity defined as the square root of $t / \rho$, where $t$ is the tangential shearing stress, and $\rho$ is the air density. The shear stress has the dimensions of velocity-squared, and is considered constant in the lowest layers of the atmosphere;

$k$ is the von Kármán constant, a constant of proportionality found by experimentation to be approximately 0.42 ;

$z_{o}$ is the roughness length;

$d$ is the zero-plane displacement and is assumed to be near roof top level in urban environments.

According to the wind profile equations described above, the wind speed in the surface boundary layer decreases with a logarithmic decrease in height. The level at which the horizontal wind speed approaches zero, and the rate at which the wind speed decreases with height, are functions of the roughness of the surface. The rate of decrease of wind speed is important in diffusion applications because the value of the exchange coefficient depends on the rate of change of the wind and not on the speed itself.

Generally, measurements of the speed of the horizontal winds at three or more heights within the unobstructed surface boundary layer are extrapolated to yield the roughness length. Figure 2 illustrates, however, that the roughness length, $z_{o}$, can be calculated from the $y$-intercept on a semilogarithmic plot of height against mean wind speed when wind speed has been measured at only two heights.

The discussion of the logarithmic wind profile has thus far assumed an environment with a neutral lapse rate. Calculation of the wind profile is least complicated for these conditions because turbulence is basically mechanical in origin. Turbulence is also generated or suppressed by thermal effects. Characterization of the wind profile under neutral conditions is, however, often unrealistic during certain times of day. Buoyancy during unstable lapse conditions will greatly enhance turbulence, whereas the converse occurs during isothermal or inversion conditions. Over rural areas, neutral conditions may occur only twice daily during the transition between nighttime stability and daytime superadiabatic lapse conditions. A neutral lapse rate, however, may be prevalent over an urban area throughout the night because the urban heat island tends to prevent nocturnal surface inversions. Using a model of the urban heat island, Oke and East (1971) showed that the combined effects of a warm and rough surface contribute to an adiabatic or neutral mixing layer over the city during the night.

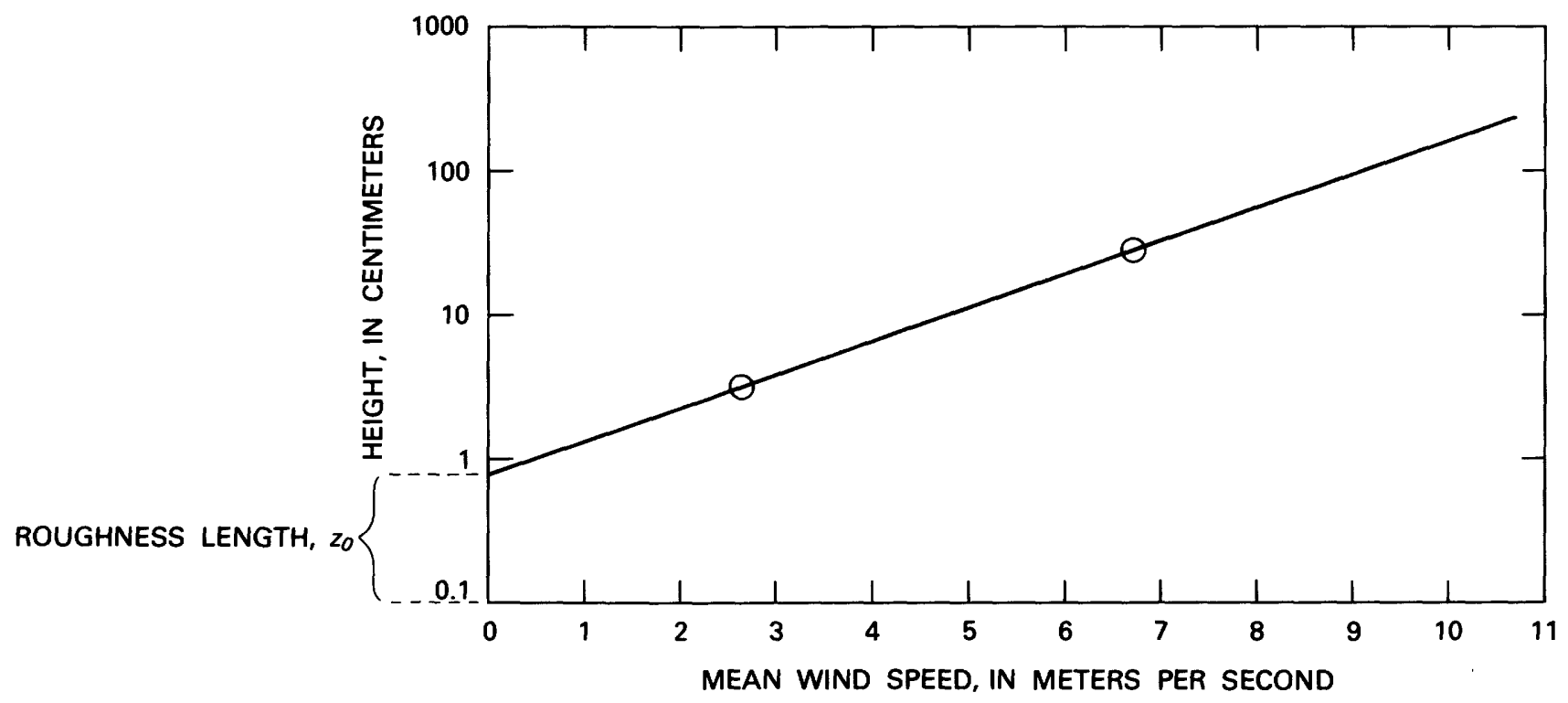

Figure 2.-Graphical determination of roughness length. In this example, the roughness length, $z_{v}$, is $0.9 \mathrm{~cm}$. 


\section{SURFACE ROUGHNESS IN URBAN ENVIRONMENTS}

The modest progress in estimating surface roughness in agricultural climatology has not been paralleled in urban applications. The relationship between surface roughness and the wind profile has been of interest in crop research as a means of predicting the turbulent transport of properties such as heat, moisture, and momentum in the surface boundary layer. In addition, the relative ease of taking field measurements of the wind profile over crops and the homogeneity of crop heights and spacing have facilitated the development of regression equations to predict the surface roughness of particular crops (Plate, 1971).

Precise measurements of the wind profile over urban structures are made difficult by instrumentation problems. The most serious difficulty is in siting an array of anemometers at proper heights. The lowest instrument must be placed above the highest surface obstacle within the surface boundary layer (Lettau, 1967). The expense and impracticality of installing high towers prohibits measurement of the wind profile in complex built-up urban areas. Because of these difficulties, urban wind profile measurements are scarce.

Where wind profiles have been determined at urban sites, measurements were usually possible because a high tower capable of supporting instruments existed by chance at a level above the highest buildings. Table 1 lists the relatively small number of cases cited in the literature where winds have been measured at urban or suburban sites. In these case studies, building heights never exceeded three or four stories, and many were lower. The spatial variation of urban surface roughness in cities with high-rises and skyscrapers has not been well documented because of these instrumentation problems.

\section{ROUGHNESS LENGTH ESTIMATES FROM SURFACE DESCRIPTIONS}

The physical and economic restrictions to making wind profile measurements above urban structures have encouraged experiments in estimating surface roughness by indirect methods. Progress in wind tunnel modeling of urban aerodynamic characteristics remains far behind that made for more homogeneous surfaces such as those presented by forests and uniformly spaced crops. The difficulties in wind tunnel modeling are caused by problems in preserving physical similarity at small scales.

Progress in estimating the surface roughness of spaced crops by the use of empirically determined regression equations (Tanner and Pelton, 1960; Kung, 1961) has stimulated investigation of the relation between aerodynamic roughness and the geometry of the surface elements. Several investigators have determined relationships between the densities and shapes of surface obstacles, and an average surface roughness (Kutzback, 1961; Stearns and Lettau, 1963). Bushel baskets and evergreen trees were used in one series of studies as control roughness elements on the smooth ice of Lake Mendota, Madison, Wis. Thus, measurements of the wind profile for various configurations of the roughness elements provided data for the design of a generalized predictive model that can be used to estimate the average surface roughness of a field from the characteristics of its roughness elements (Lettau, 1967, 1969, 1970). Use of the model is not restricted to homogeneous surfaces, as are regression models, because the model allows for density differences in fields of roughness obstacles. This allowance makes the "Lettau" model especially applicable to the nonhomogeneous building distribution of urban areas.

TABLE 1.-Roughness lengths, in centimeters, determined at urban sites

\begin{tabular}{llrl}
\hline \multicolumn{1}{c}{ City } & \multicolumn{1}{c}{ Structure } & \multicolumn{1}{c}{$z_{\text {o }}$} & \multicolumn{1}{c}{ Reference } \\
\hline Minneapolis-St. Paul, Minn. & $150-\mathrm{m}$ television tower & 200 & Deland and Binowski (1966) \\
London, Ontario & $60-\mathrm{m}$ telephone tower & 230 & Davenport (1967) \\
Philadelphia, Pa. (suburbs) & $300-$ m television tower & $22-310^{1}$ & Slade (1969) \\
Tokyo, Japan & Mast in city & 165 & Yamamoto and Shimanuki (1970) \\
Kokubunji, Japan & Mast in outskirts of city & 48 & Shiotani (1970) \\
Liverpool, England & Mast in city center & 123 & Jones and others (1970) \\
Cities in Germany & Unknown & $50-200$ & Myrup and Morgan (1972) \\
Kiev, U.S.S.R. & Unknown & 450 & Myrup and Morgan (1972) \\
Columbia, Md. & Mast in suburbs & 107 & Maisel (1971) \\
\hline
\end{tabular}

\footnotetext{
1 Values varied with wind azimuth.
} 
The simplified relation between roughness element size and density is expressed in the 1969 Lettau formula,

$$
z_{0}=0.5 h^{*} \frac{S_{1}}{S_{2}}
$$

where

$$
\begin{aligned}
z_{o}= & \text { is the roughness length, } \\
h^{*}= & \text { average height of obstacles, } \\
0.5= & \text { average drag coefficient, } \\
S_{1}= & \text { average obstacle silhouette area, } \\
S_{2}= & \text { specific area, } A / N, \text { where } A \text { is the lot area } \\
& \text { and } N \text { is the number of roughness ele- } \\
& \text { ments on the lot. }
\end{aligned}
$$

This method, applied to an urban surface, states that an average roughness length can be computed from knowledge of certain fundamental characteristics. These characteristics include the average height of buildings, a drag coefficient, the average number of buildings in a crossplane exposure to the wind, and the obstacle density - that is, the number of buildings in a given area.

Estimates of surface roughness by the Lettau formula have been applied in only a few cases. The most extensive use of Lettau's method prior to this evaluation was in an urban energy balance study done at Sacramento, Calif. (Myrup and Morgan, 1972). In Sacramento (table 2), roughness lengths were calculated from detailed field measurements of trees and buildings at 56 city locations. In another application of Lettau's method, Outcalt (1972b) used the silhouette ratio in a thermal mapping experiment along an urban-rural flight path over Ann Arbor, Mich. Outcalt did not, however, document roughness lengths. Other researchers report the use of the Lettau method in nonurban areas.

TABLE 2.-Effects of seasonal changes in vegetation on roughness length, by land use and land cover type, at Sacramento, Calif.

[Data from Myrup and Morgan (1972). Roughness lengths in centimeters]

\begin{tabular}{lrr}
\multicolumn{1}{c}{ Land use and land cover } & $\begin{array}{c}\text { Winter } \\
z_{o}\end{array}$ & $\begin{array}{c}\text { Summer } \\
z_{o}\end{array}$ \\
\hline Residential areas: & & \\
Light density & 36 & 108 \\
Medium density & 119 & 532 \\
Heavy density & 123 & 370 \\
Shopping centers & 29 & 36 \\
Central business district & 321 & 321 \\
Office buildings & 175 & 175 \\
Industrial areas & 10 & 13 \\
Open or park areas & 2 & 20 \\
Parks & 2 & 127 \\
Freeways & 4 & 4 \\
\hline
\end{tabular}

Comparison of field measurements show promising results for the application of Lettau's methods to forests (Leonard and Federer, 1973) and to field crops (Munro and Oke, 1973).

\section{CALCULATION OF SURFACE ROUGHNESS FOR BALTIMORE, MD.}

\section{THE STUDY AREA}

Baltimore, Md., had a population of 905,000 in 1970. In the same year the Baltimore Standard Metropolitan Statistical Area (SMSA) had a population of slightly more than 2 million, ranking 11th in the 29 SMSA's of 1 million or more. As a study area, therefore, Baltimore represents a multifunctional metropolis within the belt of urbanization extending from Washington, D.C., to Boston.

The sampled area is delimited on the generalized land use and land cover map in figure 3. Divided into square-kilometer strata, the total study area is $3 \mathrm{~km}$ wide, $18 \mathrm{~km}$ long, and covers $54 \mathrm{~km}^{2}$ or about one-fourth of the city surface.

The study area encompasses all major land use and land cover types from the industrial port area in the southeast, across the high-density residential and commercial buildup of the central business district (CBD), through parks and forest areas, to the lower density residential northwest area containing strips and clusters of moderate urban buildup.

Maximum relief of the city area ranges from sea level at the harbor, to slightly more than $140 \mathrm{~m}$ in the northwestern part. Local relief, however, ranges from less than $6 \mathrm{~m}$ to a maximum of $67 \mathrm{~m}$ within the $1-\mathrm{km}^{2}$ grid cells of the study area. The greater local relief occurs in the fall zone near the center of the city and along the narrow Jones Falls Creek valley extending to the north-northwest. Although local relief may have significant effects on perturbations in the wind field (Anderson, 1971), and ultimately on the surface roughness, evaluation of topographic influence is beyond the scope of this study.

\section{SAMPLING SGHEME}

Probability sampling was used to overcome the practical limitations of measuring every roughness element in the study area. Areally stratified random sampling was applied to the $\mathbf{5 4}$ grid cells shown in figure 3. Because the sampling density was six random elements per cell, the total sample contained 324 elements. The sample elements averaged 0.8 ha. The areal character of each sample reduced the probability of error in representation that is typical of the traditional point sample. Sampling was dense 


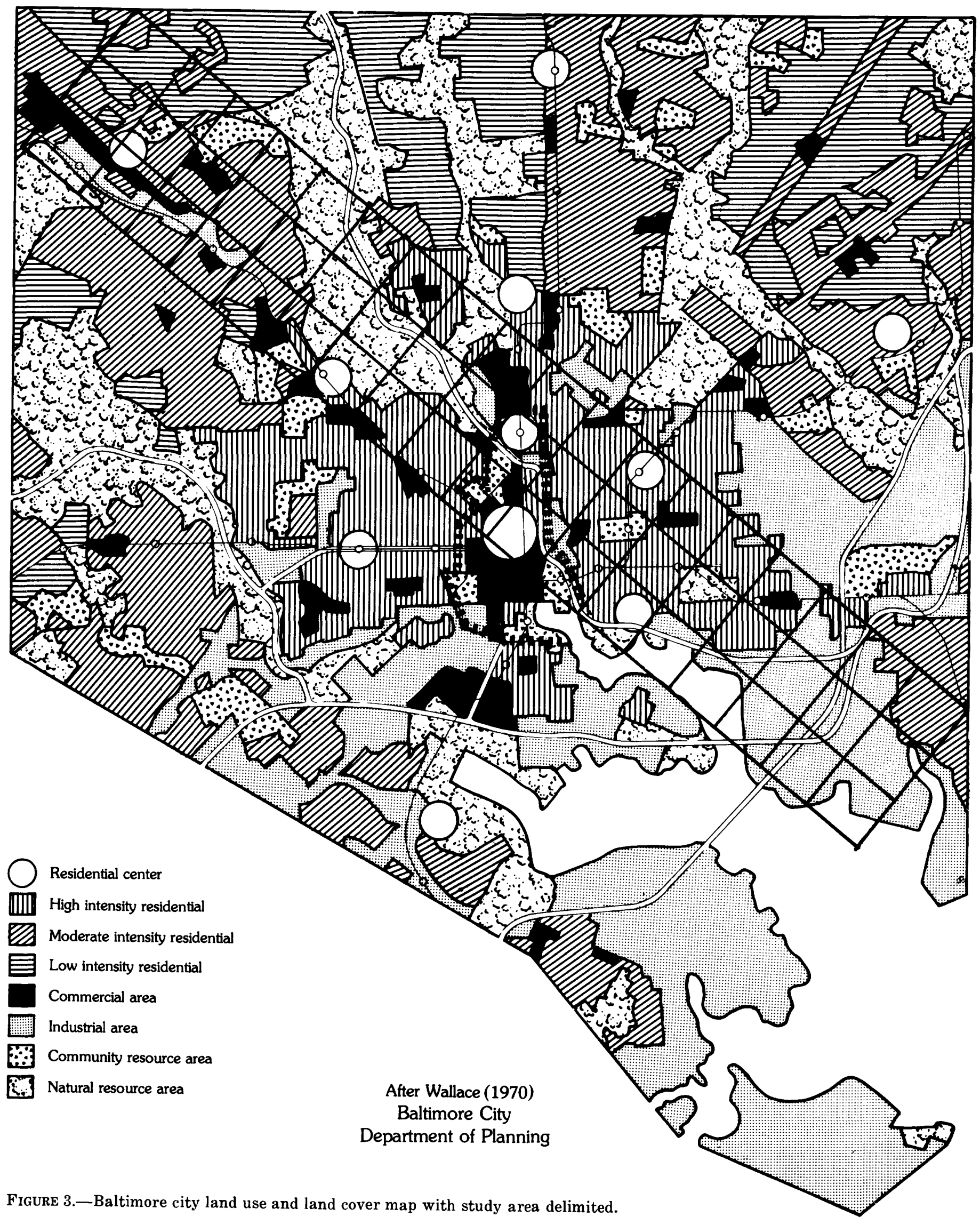


enough that each land use and land cover type was included.

\section{PILOT STUDY FOR ACQUISITION OF DIMENSIONAL DATA}

Three kinds of dimensional data were required for buildings as the roughness elements on sample plots: (1) their height (2) their silhouette areas, and (3) the density of their field. The sensitivity and limitations of the Lettau formula, with regard to the economical acquisition of building and plot dimensions, were studied at a 1.6 ha residential plot about $3.2 \mathrm{~km}$ northwest of the downtown center. Figure 4 is an isometric drawing of the buildings on this plot, referred to here as the Druid Hill test plot.

The results of the test plot study were used to compare the efficiency of retrieving data from different sources so that dimensioning procedures compatible with the Lettau formula could be standardized. Data sources included Sanborn insurance maps, low-altitude aerial photographs, and field measurements.

Sanborn maps provided the most efficient data source for building and plot dimensions (fig. 5). The Sanborn map series, commonly used by city engineering and planning departments, was available at scales of $1: 1,200$ and $1: 24,000$. Horizontal measurements of buildings and plot perimeters were transferred from these maps to individual sample plot worksheets similar to the one for Druid Hill (table 3). Worksheets facilitated the calculation of a weighted average silhouette area for the field of roughness obstacle elements dimensioned on each plot. Low-level aerial photographs at a scale of $1: 6,000$ provided supplementary information on the distribution of vegetation and on the validation of open areas.

Heights, in feet, are shown for all nonresidential buildings on the Sanborn maps. Residential building heights, comprising a large proportion of the samples, are shown only by the number of stories.

PLOT SIZE: 131 meters $X 124$ meters $=16,219$ meters $^{2}(1.62$ hectares)

EXPLANATION SPECIFIC AREA: (PLOT AREA/N) $=2,027$ meters $^{2}$ AVERAGE BUILDING HEIGHT BY FIELD MEASUREMENT: 9.3 meters AVERAGE BUILDING HEIGHT FROM NUMBER OF STORIES: 9.4 meters

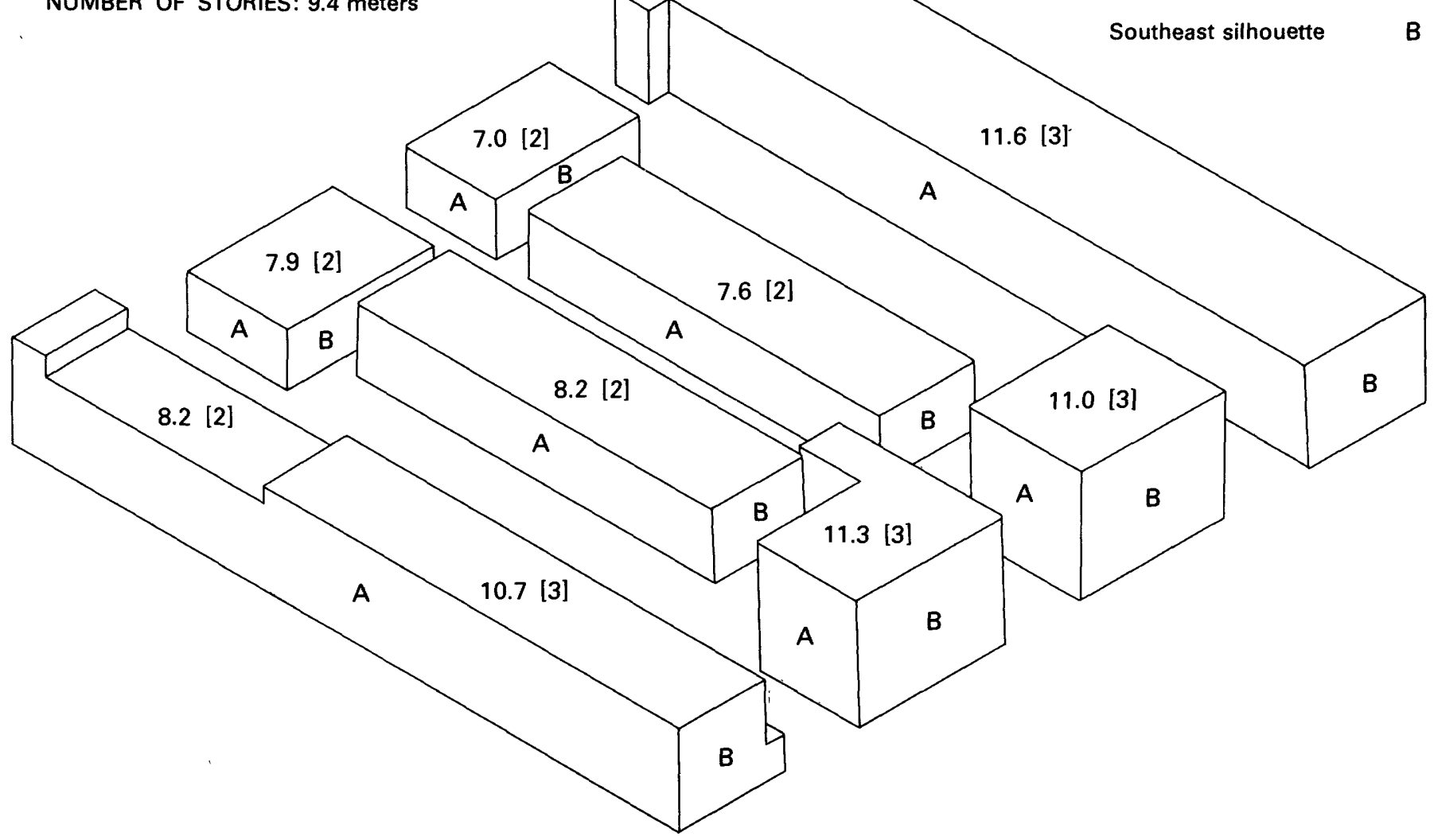

FIgURE 4.-Isometric drawing of the Druid Hill test plot. 
TABLE 3.-Druid Hill test plot dimensional worksheet

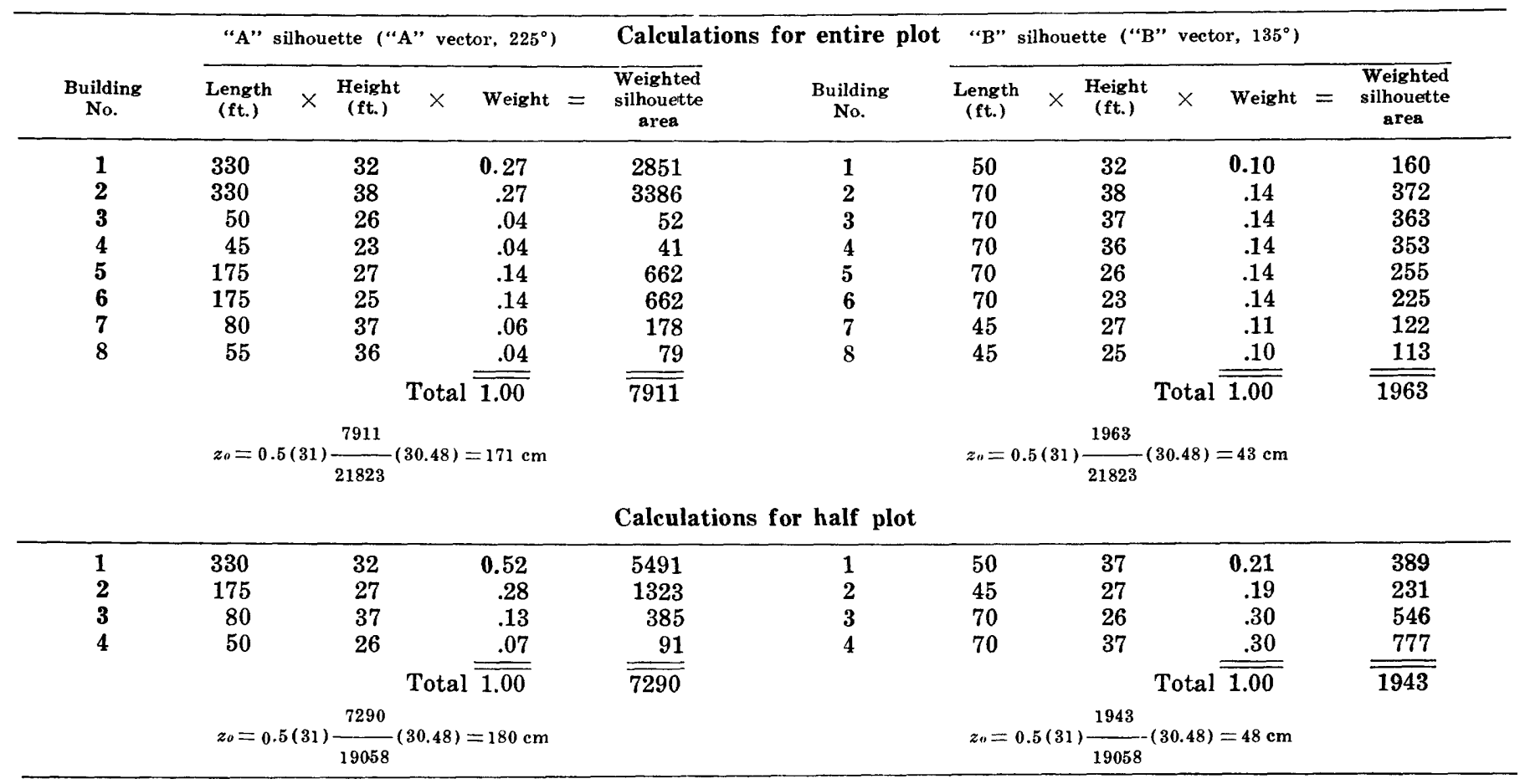

Building heights in the Druid Hill test plot were calculated from trigonometric solutions to clinometer measurements. After field measurements of a range of residential building types, reliable building height information was subsequently determined from the number of stories. Sensitivity testing of height values in the Lettau formula (eq. 4) showed that precision clinometer measurements improved the accuracy of the roughness lengths by only a few centimeters compared to indirect height estimates from the number of stories.

The determination of the average building silhouette area for a given plot also required the development of a particular methodology. As shown in figure 4, rectangular buildings have two distinctive silhouettes, designated " $A$ " and " $B$ " hereafter.

An "effective silhouette area" as a function of the wind azimuth, also needs to be defined. In only two unique cases (and their reciprocal exposures) was the wind perpendicular to either the A or B silhouettes. Variability of the azimuth of urban surface winds (Graham, 1968) indicates that winds will most likely intercept portions of both silhouettes. It was therefore necessary to calculate two average silhouette areas for each plot and to sum the effective areas of each.

Unless all roughness elements were of similar size, simple numerical averages of $\mathrm{A}$ and $\mathrm{B}$ silhou- ette areas sometimes produced results that did not represent the average silhouette. Significant size differences within a heterogeneous mix of buildings indicated that each structure does not have equal influence on the aerodynamic process. Proportional weighting of individual building silhouette areas overcame this problem. Table 3 shows the worksheet calculations of the weighted silhouette areas of structures in the Druid Hill test plot. Weights were determined by ratioing the individual silhouette area to the sum of the silhouette areas.

An assessment was made of the minimum plot size necessary to ensure representative roughness lengths in a given sample. It was found that test plots with relatively homogeneous building geometry, such as the Druid Hill test plot, could be reduced in size without a loss of information. Calculations of building silhouettes based on data from slightly less than half the original sample areathat is, four buildings on 0.7 ha rather than eight buildings on 1.6 ha-are shown in the worksheet (table 3). Depending on the wind azimuth, roughness lengths calculated from data for the small area differed only 5 to 10 percent from those calculated from data for the entire area.

When building geometry in a sample plot is heterogeneous, particularly in a central business district where building geometry abruptly changes 


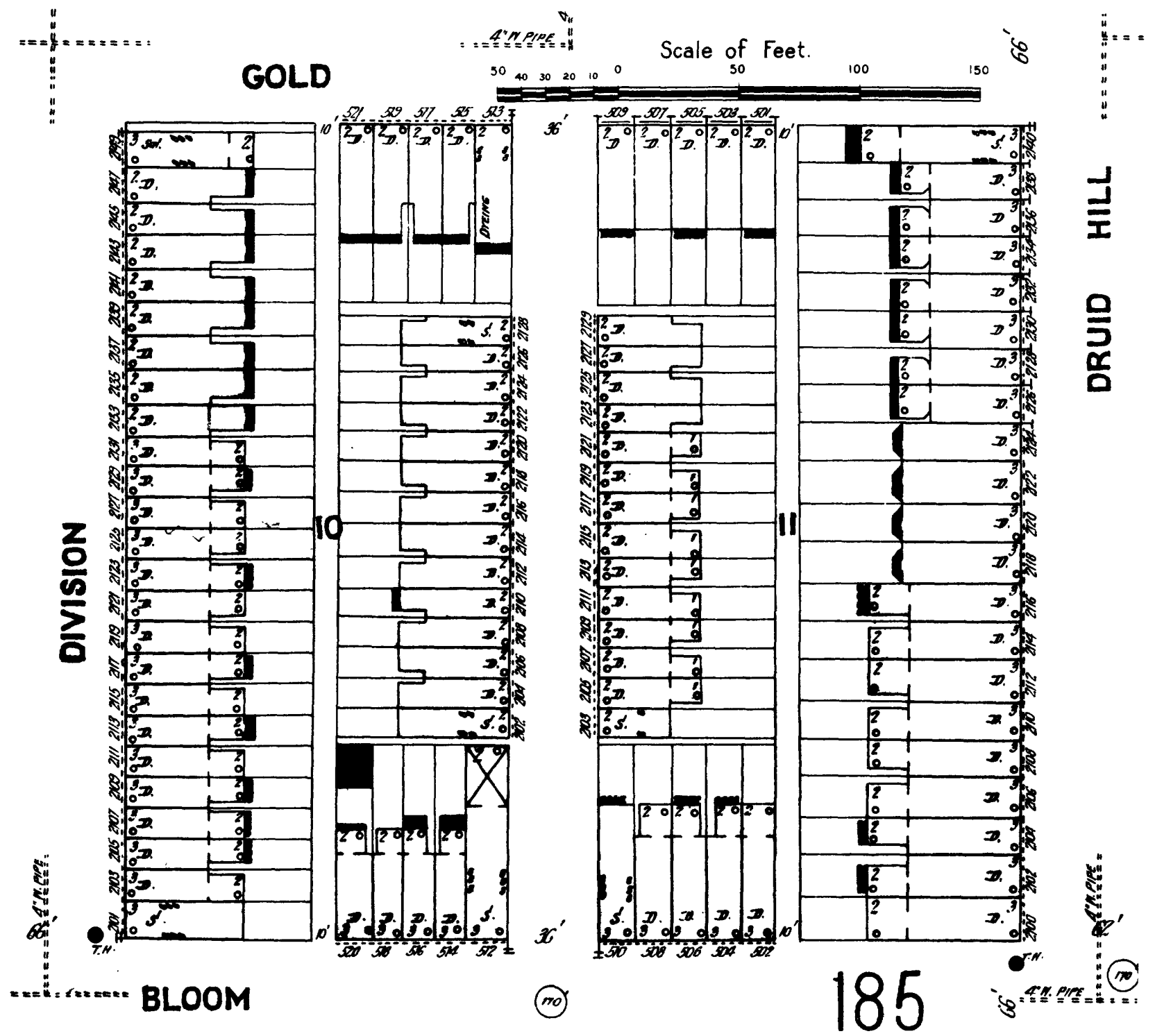

Figure 5.-Sanborn map of the Druid Hill test plot.

within short distances, the minimum plot size must be set carefully. To accurately represent a segment of such a heterogeneous surface, both extremes of the geometric variation in a single plot must be characterized. For example, the highest roughness value calculated was for a 1.4 ha-sample plot containing two 35-story buildings intermixed with three other buildings ranging from only 2 to 7 stories. If a plot containing only one of the 35-story high-rise buildings had been sampled separately, the calculated roughness length would have been 63 percent higher, and would not have represented the entire field of roughness elements. Conversely, if the plot size is excessively large, it will overgeneralize rather than actually measure the true local influence of the building geometry.
Delimiting the perimeter of a sample areal plot may also influence the calculated roughness length. Table 4 shows the effect of different lot sizes in a

TABLE 4.-Relation between plot size and roughness length

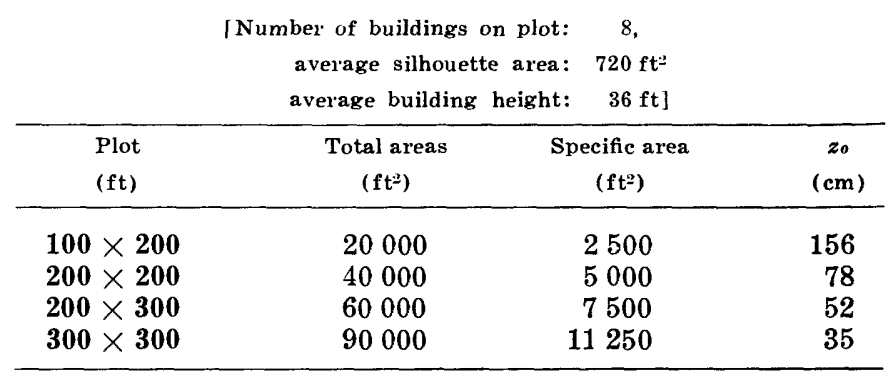


hypothetical plot containing eight residential buildings. A linear relationship exists between the plot area and the calculated roughness length.

Street centerlines were used as the boundary between adjacent built-up plots within the urban area. Careful judgment, however, is required to determine the boundaries of a sample area when they are ill-defined. In the case of a typical shopping plaza, for example, it was necessary to determine whether parking lots should be included with the building complex. With land use and land cover as a criterion, the parking areas were considered inseparable from the building complex, since a typical plaza contains both. In other cases where the perimeter was less well defined, the principal criterion for delimiting the plot was how much area was necessary to adequately represent the actual surroundings.

\section{TESTING THE EFFECTS OF WIND VARIATIONS ON BUILDING SILHOUETTES}

Rectangular buildings are very sensitive to the azimuth of wind attack and their effectiveness as a roughness obstacle is significantly reduced when winds are not perpendicular to the silhouette face. This relationship may be inferred from the $A$ and $B$ silhouettes of the buildings illustrated in figure 4 . A wind shift away from the direction perpendicular to silhouette A decreases the effectiveness of silhouette $A$ as a roughness obstacle. At the same time, although the shift increases the effectiveness of silhouette $B$ as an obstacle, because the wind is more perpendicular to $B$, the wall area of $B$ still presents a much smaller face than $\mathrm{A}$.

The change in silhouette exposures occasioned by shifts in wind direction raises several questions regarding the calculations of surface roughness from an obstacle element description: (1) is the wind direction significant in the computation of roughness length? (2) are all building shapes sensitive to the wind azimuth? and (3) what are the parameters in the evaluation of the effect of the azimuth?

A method for mathematical rotation of each sample plot containing buildings was devised to test the effect of different wind azimuths on calculated roughness lengths. Starting with a vector normal to one of the building walls, a $90^{\circ}$ rotation offers all possible direct or reciprocal exposures to the wind. The wind direction was changed in steps of $15^{\circ}$ to give a total of seven calculated roughness values for each sample plot. Continued rotation would not provide additional information because the changes in silhouettes would be merely repeated as reciprocal exposures.
Orientation vectors for the $A$ and $B$ silhouettes were determined along with the building and plot dimensions. The orientation vector is defined as the perpendicular to the silhouette face, expressed as an azimuth. Each sample plot, therefore, has its own "A vector" and " $B$ vector" to describe its orientation to a prevailing wind direction.

Plot rotation was accomplished mathematically by specifying the total silhouette area exposed to a particular wind azimuth; then calculating the roughness length at each increment of rotation. As shown in figure 6 , there are two unique cases in a $90^{\circ}$ rotation when the wind intercepts either the $\mathrm{A}$ or B silhouettes perpendicularly. Winds at all other azimuths intercept only portions of each silhouette.

The total effective silhouette area was calculated by adding the individual contributions of the $A$ and $B$ silhouette faces. For example, the exposed portion of silhouette A was determined by measuring the angular difference between the perpendicular to the silhouette, or A vector, and a specified wind direction. This difference is called a silhouette depletion factor, or angle $A$. The effective exposure of the A silhouette face was then calculated as the cosine of angle $A$.

For example, if the wind azimuth in a test plot is the same as the $A$ vector, the difference will be $0^{\circ}$ and the cosine 1.0. Therefore, the A silhouette is not depleted when the wind is perpendicular. Because $\cos 45^{\circ}=0.7071$, the A silhouette area declines to 71 percent of its original value when the wind intercepts the silhouette at an azimuth of $45^{\circ}$ from the perpendicular or $\mathrm{A}$ value. The exposure for the $B$ silhouette is calculated similarly, then added to the A portion to specify the total exposed silhouette as a function of the wind direction.

Figure 6 illustrates the effects of changing wind azimuths on the roughness values of the Druid Hill test plot. Starting with the perpendicular to the A silhouette face at wind azimuth $225^{\circ}$, the first $30^{\circ}$ of plot rotation (from $225^{\circ}$ to $195^{\circ}$ ) only slightly influences the roughness length. With the next $30^{\circ}$ of rotation (from $195^{\circ}$ to $165^{\circ}$ ), the roughness length decreased to 71 percent of its initial value. In this segment of rotation, the effect of $A$ silhouettes begins to diminish more rapidly, whereas the appearance of the $B$ silhouettes in the wind field brings in relatively smaller interception areas. The final $30^{\circ}$ of plot rotation (from $165^{\circ}$ to $135^{\circ}$ ) results in the most significant reduction in the roughness length. All of the larger A silhouettes are depleted, leaving only the smaller B silhouettes exposed to 


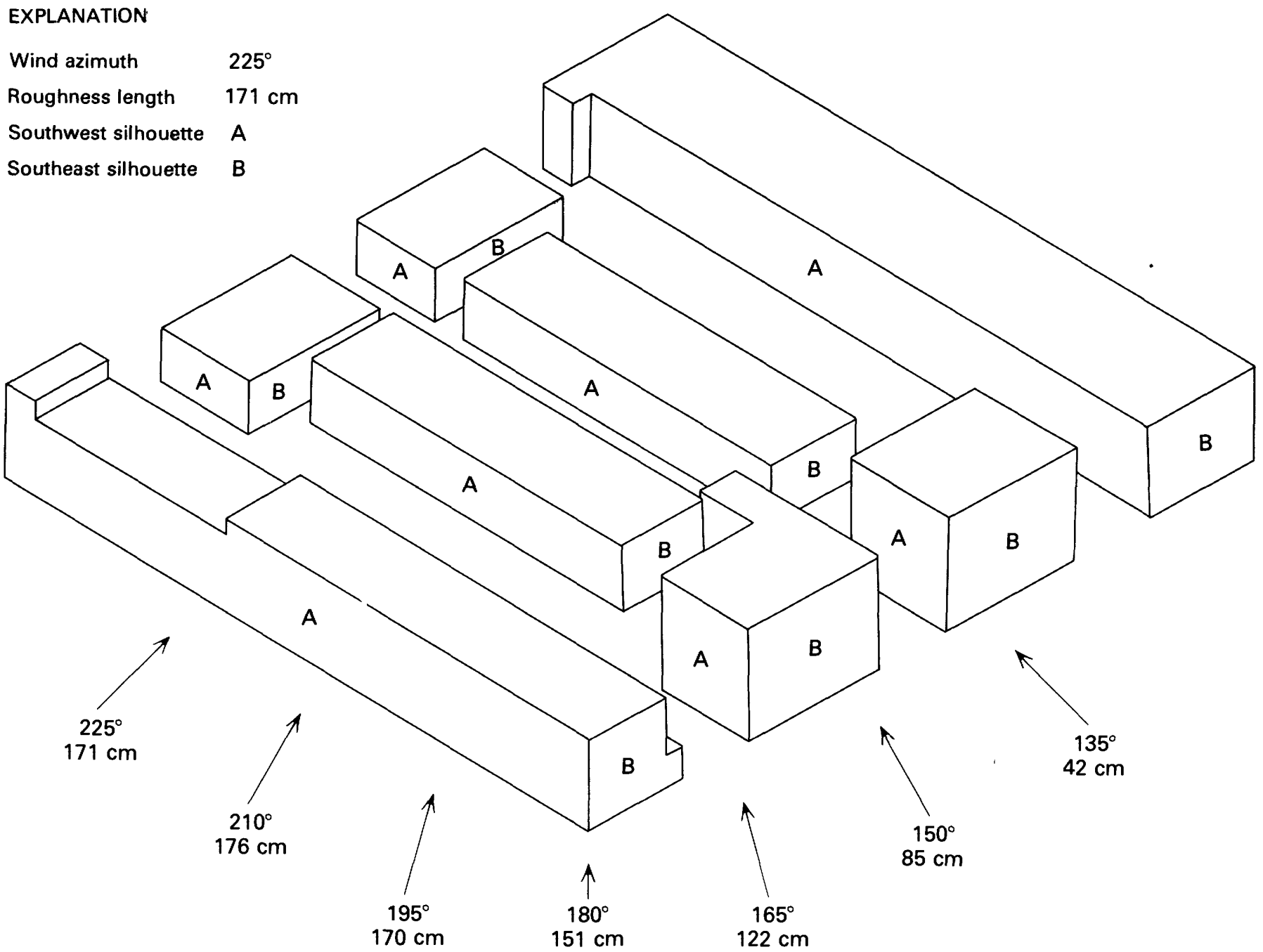

FIgURE 6.-Effects of wind direction on surface roughness.

the wind. The final roughness length, after $90^{\circ}$ of rotation, is one quarter of its original value.

The amount of change in the calculated roughness value, as a function of the wind azimuth, is related to the ratio of the $\mathrm{B}$ to $\mathrm{A}$ silhouette areas. If both silhouette areas are identical, as in the case of cubical forms, little variation in surface roughness will be expected from plot rotation. The set of samples in this study, however, contains a wide, yet representative, range of silhouette area ratios. This variation in silhouette area ratios and its effects on surface roughness, is assessed both statistically and aerodynamically.

To compare statistically the variations in surface roughness with the range of building configurations, the coefficient of variation (the ratio of the standard deviation of a variable to its mean) is employed.
For the Druid Hill test plot, the coefficient of variation of the roughness lengths is 0.39 and was calculated from a standard deviation of $51 \mathrm{~cm}$ divided by a mean of $131 \mathrm{~cm}$. This coefficient may now be meaningfully compared with all others in the sample set to evaluate the effects of plot rotation, and thus the effects of wind direction on surface roughness.

The distribution of coefficients of variation of roughness lengths for all building plot samples is illustrated in figure 7. This histogram, with its descriptive statistics, provides a means for evaluating the statistical significance of plot rotation on the range of building configurations. The coefficients of variation ranged from 0.04 to 0.54 , with a mean value of 0.19 , resulting in a positively skewed distribution. The dispersion about the mean ranged from 0.08 to 0.30 , corresponding to minus and plus one standard deviation. 


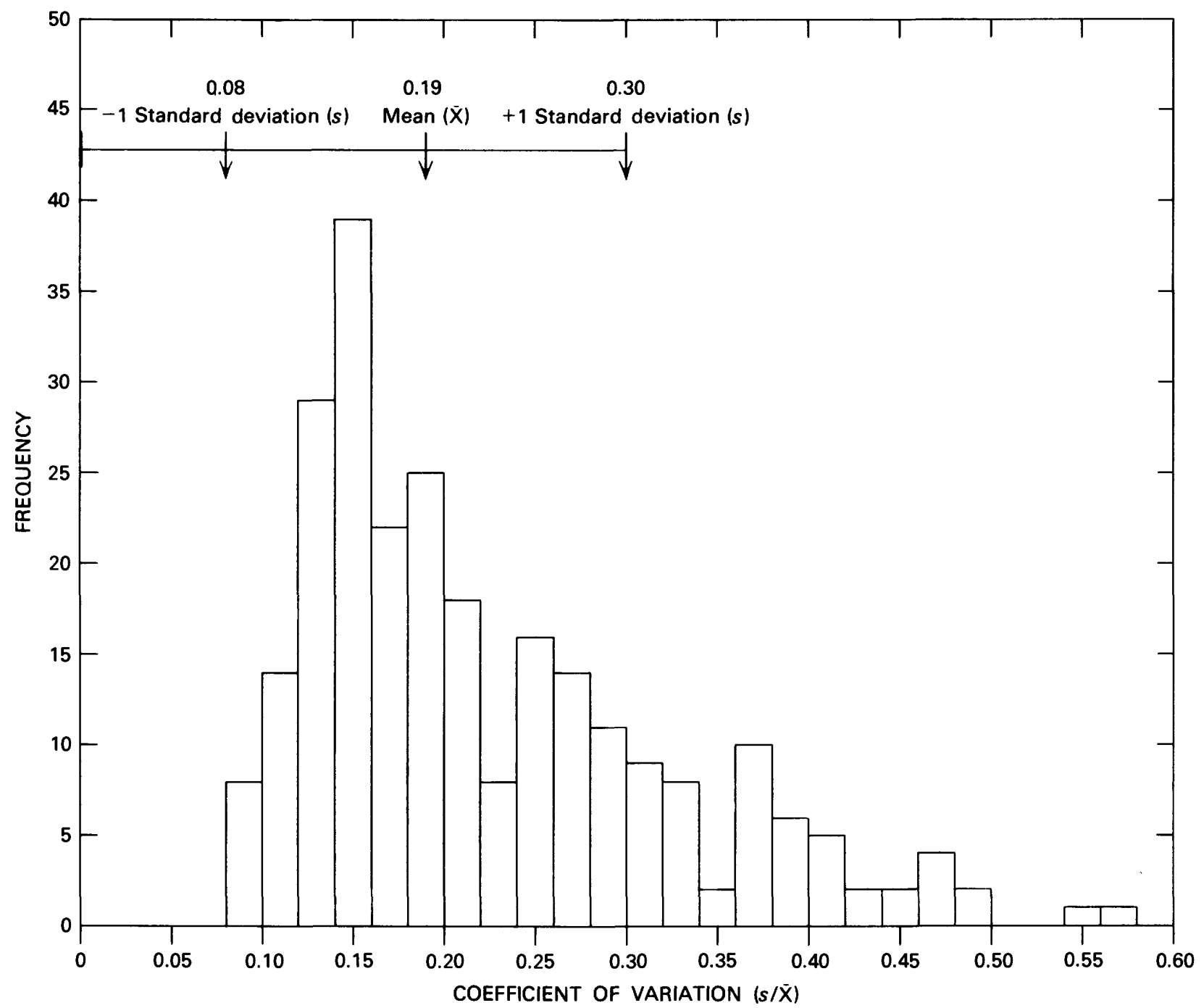

Figure 7.-Histogram of coefficients of variation of roughness lengths, from plot rotation.

An examination of the geometry of the buildings in the samples beyond the one standard deviation portion of the distribution (coefficients greater than 0.30 ) revealed the presence of elongated structures such as exceptionally long row houses, and warehouses. Typical - width-to-length ratios of these buildings were 0.16 and smaller. When this ratio exceeded 0.22 , the building geometry was represented by coefficients of variation of the roughness within the one standard deviation portion of the histogram (coefficients of 0.30 and smaller). The transition between the two regions of the distribution was characterized by a width-to-length ratio of approximately 0.20 . The statistical variation was, therefore, found to be related to the properties of the buildings.

Further examination of sample plots with coefficients of variation less than 0.30 , or within one standard deviation of the mean, showed that some sample plots had buildings with small width-tolength ratios. This apparent anomaly of small width-to-length ratios, without the expected high coefficient of variation of roughness lengths, was explained by the particular plot orientations. All these anomalous plots had buildings arranged in quadrangle or L-shaped configurations. As the long silhouette of one set of buildings is diminished with a shift in wind azimuth, the silhouette area reduction is compensated for by the simultaneous increase in the long silhouettes of their perpendicularly oriented companion buildings.

This type of sensitivity analysis showed that for a wide range of building geometries and layouts in 262 sample plots, only 16 percent were significantly sensitive to varying wind azimuths. Although 16 percent of the plots appeared statistically sensitive 
to changes in the wind azimuths, the actual variability of surface winds suggests that the mean roughness length calculated from values acquired by the plot rotation is an acceptable generalization. The unlikelihood that a wind would be sustained from a single direction is verified by an analysis of urban winds at Fort Wayne, Ind. (Graham, 1968). Graham found that near the city center, one standard deviation of the azimuth angle of the winds was $20^{\circ}$, or a total variation of $40^{\circ}$ about the mean azimuth. These findings provide confidence that the mean value of surface roughness determined from plot rotation is sufficiently representative to be mapped.

\section{MODIFICATIONS AND PROCESSING OF DIMENSIONAL DATA}

One of the primary objectives of this study was to evaluate building geometry as a means of indirectly estimating the aerodynamic properties of urban land use and land cover classes. The urban surface, however, contains a variety of forms other than buildings. A significant proportion of the sample plots are without buildings and therefore require separate consideration. Table 5 shows data on sample plots according to the type of plot cover and formula used to describe surface roughness.

TABLE 5.-Number and percent of sample plots, by type of cover and surface roughness formula used

\begin{tabular}{|c|c|c|c|}
\hline $\begin{array}{c}\text { Plot } \\
\text { cover }\end{array}$ & $\begin{array}{c}\text { No. of } \\
\text { samples }\end{array}$ & Percent & $\begin{array}{c}\text { Formula } \\
\text { used }\end{array}$ \\
\hline Buildings & 199 & 61 & Lettau \\
\hline Buildings \& trees & 63 & 20 & Lettau modified \\
\hline Woods & 30 & 9 & Kung modified \\
\hline Open areas & 32 & 10 & $\left({ }^{1}\right)$ \\
\hline Total & 324 & 100 & \\
\hline
\end{tabular}

${ }^{1}$ Value assigned

Sixty-one percent of the sample plots contained buildings and other urban structures directly compatible with the dimensional requirements of the Lettau formula (eq. 4). An additional 20 percent of the plots contained buildings intermixed with rows and clusters of trees. The increase in aerodynamic roughness caused by trees was accounted for in the Lettau formula by an increase of the drag coefficient in proportion to the amount of tree cover. The proportional, or linear, relation between obstacle density and roughness length was previously determined (table 4). A field surveillance of tree heights and frequency of occurrence in rows was used to establish the categories shown in table 6 .
TABLE 6.-Drag coefficients for different numbers of tree rows and tree heights

\begin{tabular}{ccc}
\hline $\begin{array}{c}\text { Drag } \\
\text { coefficient }\end{array}$ & $\begin{array}{c}\text { Average no. } \\
\text { of tree rows }\end{array}$ & $\begin{array}{c}\text { Tree height } \\
(\mathrm{m})\end{array}$ \\
\hline $\mathbf{0 . 6 0}$ & 1 & $<10$ \\
$\mathbf{0 . 6 5}$ & 1 & $>10$ \\
$\mathbf{0 . 7 0}$ & 2 & $<10$ \\
$\mathbf{0 . 7 5}$ & 2 & $>10$ \\
$\mathbf{0 . 8 0}$ & 3 & $<10$ \\
$\mathbf{0 . 8 5}$ & 3 & $>10$ \\
$\mathbf{0 . 9 0}$ & 4 & $>10$ \\
$\mathbf{0 . 9 5}$ & 4 & $>10$ \\
\hline
\end{tabular}

The average drag coefficient of 0.5 in formula (4) was increased in each of the eight steps of increasing roughness. Although the method is crude, the results approximate the probable linear increase of roughness values up to a maximum. This procedure avoids the dimensioning of tree silhouette areas, a problem beyond the scope of this study.

To test the use of the modified drag coefficient, a pilot study was performed on a low-density residential plot containing tree-lined streets. The distribution of trees, determined from aerial photographs and field observations, placed the sample plot in the class of four tree-rows with average heights greater than $10 \mathrm{~m}$ (table 6 ). The roughness length of $59 \mathrm{~cm}$ calculated for this plot showed that inclusion of tree rows produced a fully roughened surface that was nearly double the original value of $31 \mathrm{~cm}$ for buildings alone. The results are conservative when compared to the value of $96 \mathrm{~cm}$ calculated for a wooded plot with tree heights averaging $10 \mathrm{~m}$ by the crop regression method described below.

Wooded plots, comprising 9 percent of the sample, did not lend themselves to the geometric dimensioning required by the Lettau method. Instead, a regression equation devised by Kung (1961) was employed for estimating the roughness lengths of tall crops. The regression equation relating plant height to the aerodynamic roughness of evenly spaced crops is:

$$
\log _{10} z_{o}=a+b \log _{10} h
$$

where $a$ and $b$ are empirically determined constants, and $h$ is the average crop height.

The constants $a$ and $b$ in the equation are -1.24 and 1.19 , respectively. These values are in good agreement with those derived by numerous other investigators for vegetated surfaces ranging from short grasses to tall trees (Sellers, 1965).

Aerial photographs revealed that the distribution of vegetation in the wooded sample plots varied greatly. Sample plots 0.4 ha or larger were classi- 
fied as wooded if 30 percent or more of the area was covered by trees. Average tree heights were determined from field data.

The fourth group of cover types listed in table 5 is open areas with no significant building or tree obstacles. Open areas are 10 percent of the total number of samples and consist of grass, wide highways, brush and other low vegetation, and relatively empty railroad yards. In addition, some samples represented lakes or estuaries. Because no technique was available to deal with these open areas, roughness lengths were assigned to each sample plot according to a description of similar surfaces for which field measurements were cited in the literature. Table 7 lists the different types of open area surfaces, their assigned roughness lengths, and their source references. Table 8 summarizes the procedure for organizing the surface description data according to the three principal cover types and associated formulas described above.

\section{BASIC DATA DESGRIPTION}

The frequency distribution of all the 324 roughness lengths is plotted as a histogram in figure 8 . The shape of the histogram shows that the distribution is bounded, that is, no negative or zero values are in the sample. The high positive skewness reflects the extreme values of surface roughness derived from the samples from the CBD. The depar-
TABLE 7.-Roughness lengths, in centimeters, assigned to open areas

\begin{tabular}{|c|c|c|c|}
\hline $\begin{array}{l}\text { Type of } \\
\text { surface }\end{array}$ & $\begin{array}{l}\text { No. of } \\
\text { occur- } \\
\text { rences }\end{array}$ & $\begin{array}{c}\text { Assigned } \\
z_{o}\end{array}$ & Source \\
\hline Estuary & 11 & 1 & $\begin{array}{c}\text { Plate }(1971) \text {. Values from } \\
0.03 \mathrm{~cm} \text { to } 0.3 \mathrm{~cm} \text {. Set } \\
\text { to } 1 \mathrm{~cm} \text { for convenience. }\end{array}$ \\
\hline Small lakes & 2 & 2 & $\begin{array}{l}\text { Maisel (1971) From field } \\
\text { measurements in Co- } \\
\text { lumbia, Md. }\end{array}$ \\
\hline Grassy shoreline & 1 & 4 & $\begin{array}{l}\text { Plate (1971). For grasses } \\
30 \mathrm{~cm} \text { high. }\end{array}$ \\
\hline Grassy field & 2 & 5 & $\begin{array}{l}\text { Slade (1968). From a } \\
\text { value for lawns. }\end{array}$ \\
\hline Tall weeds & 2 & 8 & $\begin{array}{l}\text { Maisel (1971). Field } \\
\text { measurements. }\end{array}$ \\
\hline $\begin{array}{l}\text { Streets \& } \\
\quad \text { sidewalks }\end{array}$ & 4 & 8 & $\begin{array}{l}\text { Maisel (1971). Field } \\
\text { measurements of streets } \\
\text { prior to development. }\end{array}$ \\
\hline Railroad yards & 4 & 8 & $\begin{array}{l}\text { Maisel (1971). From. } \\
\text { similarity to streets } \\
\text { and sidewalks. }\end{array}$ \\
\hline Brush & 3 & 14 & $\begin{array}{l}\text { Szeicz and others }(1969) \text {. } \\
\text { For brush with heights } \\
\text { of } 135 \mathrm{~cm} \text {. }\end{array}$ \\
\hline $\begin{array}{l}\text { Walls \& low } \\
\text { vegetation }\end{array}$ & 1 & 30 & $\begin{array}{l}\text { Rosenberg (1966). From } \\
\text { field measurements of a } \\
210 \mathrm{~cm} \text { high shelter. }\end{array}$ \\
\hline
\end{tabular}

ture from symmetry in the distribution is, therefore, explained by the extremely large silhouette areas of high-rise buildings. Statistics for the entire sample are summarized in table 9.

TABLE 8.-Procedure for organizing surface description data

\begin{tabular}{|c|c|c|c|}
\hline Type of cover. & Buildings and trees & Woods & Open areas \\
\hline Number of samples & 262 & 30 & 32 \\
\hline Percent of total & 81 & 9 & 10 \\
\hline $\begin{array}{l}\text { Data sources: } \\
\text { Sanborn maps } \\
\text { aerial photographs } \\
\text { zoning maps } \\
\text { field checks }\end{array}$ & $\begin{array}{l}\mathrm{X} \\
\mathrm{X} \\
\mathrm{X} \\
\mathrm{X}\end{array}$ & $\begin{array}{l}\mathrm{X} \\
\mathrm{X}\end{array}$ & $\begin{array}{l}\mathrm{X} \\
\mathrm{X}\end{array}$ \\
\hline Data collected & $\begin{array}{l}\text { Horizontal dimensions of buildings } \\
\text { and plot } \\
\text { Vertical dimensions of buildings } \\
\text { Plot orientation }\end{array}$ & $\begin{array}{l}\text { Plot size } \\
\text { Tree heights }\end{array}$ & $\begin{array}{l}\text { Plot size } \\
\text { Surface description }\end{array}$ \\
\hline $\begin{array}{l}\text { Preprocessing } \\
\text { calculations } \\
\text { (largely manual) }\end{array}$ & $\begin{array}{l}\text { Area: } \\
\text { Specific area }\left(\mathrm{S}_{2}\right) \\
\text { Average A silhouette area } \\
\left(\mathrm{S}_{1}(\mathrm{~A})\right) \\
\text { Average B silhouette area } \\
\left(\mathrm{S}_{1}(\mathrm{~B})\right) \\
\text { Average building height }\left(h^{*}\right) \\
\text { Average drag coefficient }\end{array}$ & $\begin{array}{l}\text { Average heights } \\
\text { Average density } \\
\left(z_{o} \text { from Kung }\right. \\
\text { formula }(5))\end{array}$ & $\begin{array}{l}\text { Surface description } \\
\text { matched to case studies }\end{array}$ \\
\hline $\begin{array}{l}\text { Calculations } \\
\text { (largely by computer) }\end{array}$ & $\begin{array}{l}\text { Preprocessed data in computer } \\
\text { program for plot rotation and } \\
z_{o} \text { calculations }\end{array}$ & $\begin{array}{l}\text { Kung estimate modified } \\
\text { according to density }\end{array}$ & \\
\hline Output & $\begin{array}{l}\text { Ready to map mean } z_{n} \text { derived } \\
\text { from plot rotation }\end{array}$ & $\begin{array}{l}\text { Ready to map modified } \\
\text { Kung estimate }\end{array}$ & $\begin{array}{l}\text { Ready to map best } \\
\text { estimate }\end{array}$ \\
\hline
\end{tabular}




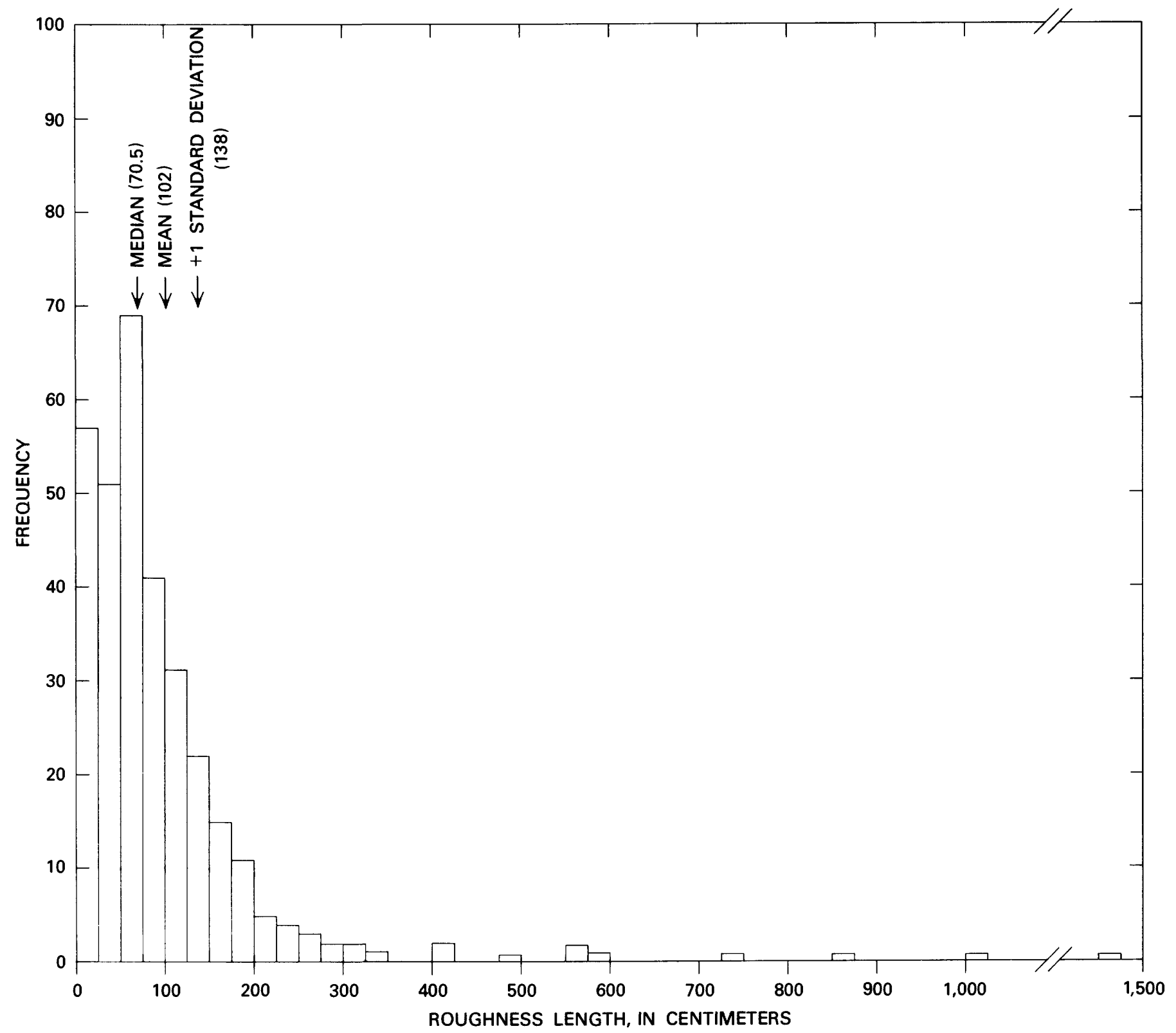

Figure 8.-Histogram of 324 roughness lengths.

TABLE 9.-Summary of roughness length data in centimeters

[Sample size is 324 ]

\begin{tabular}{lc}
\hline \multicolumn{1}{c}{ Statistic } & $z_{o}$ \\
\hline Maximum & 1468 \\
Minimum & 1 \\
Range & 1467 \\
Mean & 102 \\
Median & 70.5 \\
Standard deviation & 138 \\
Range after 8 highest & \\
values removed & 416 \\
\hline
\end{tabular}

DESCRIPTIONS OF LAND USE AND LAND COVER CLASSIFICATION SYSTEMS

The three land use and land cover classification systems used to evaluate the regional distribution of surface roughness in Baltimore are: (1) U.S. Geological Survey Level II land use and land cover classification system (Anderson and others, 1972); (2) city of Baltimore Zoning Ordinance System; and (3) an experimental classification scheme for physical-environmental applications patterned after the U.S. Geological Survey system and referred to herein as Baltimore Level III. 
TABLE 10.-Land use and land cover in Baltimore according to three different classification systems

[Values are expressed as a percentage of the total sample]

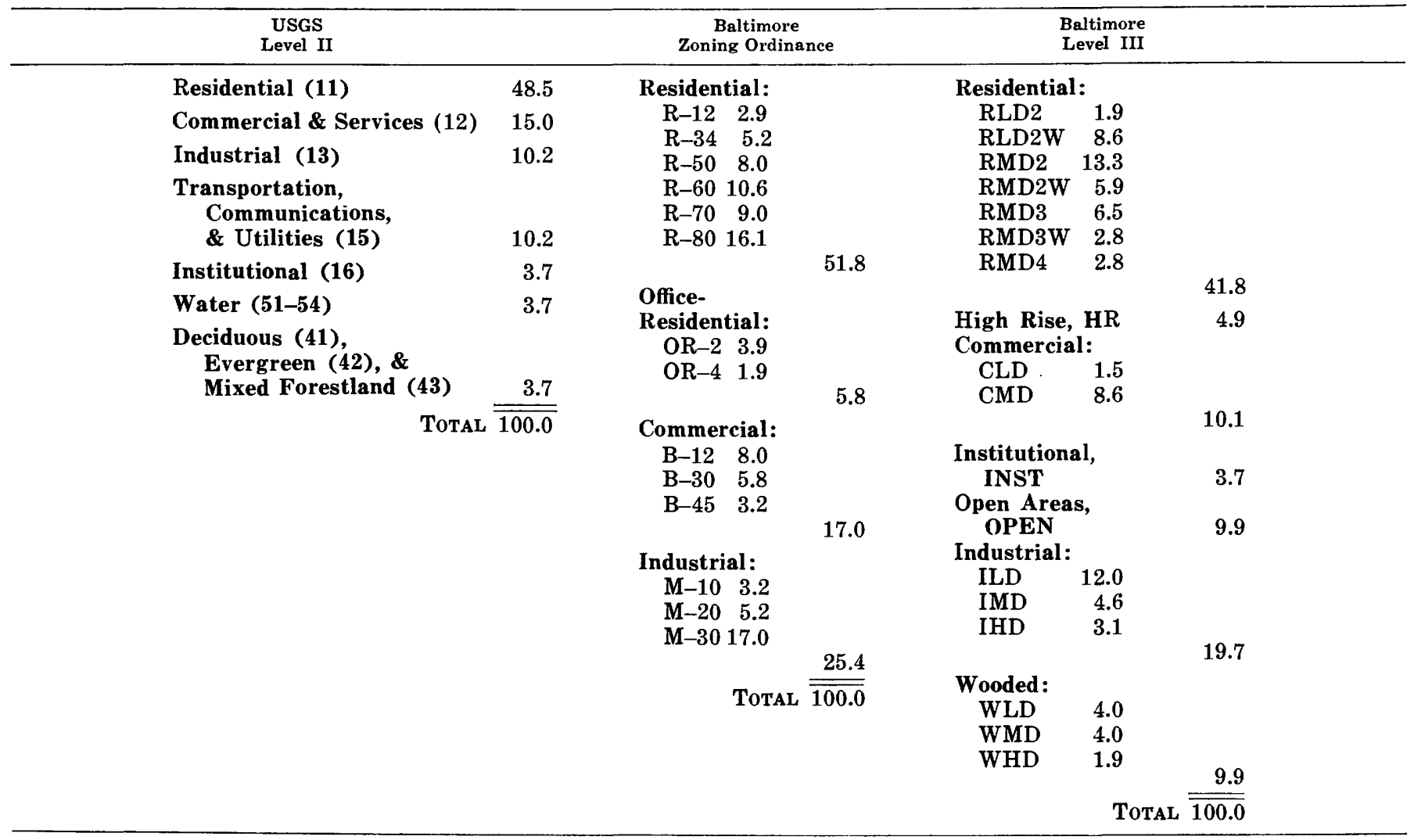

The percentage of land use and land cover in Baltimore organized according to the categories of land use and land cover in the three classification systems are shown in table 10 . These percentages compare favorably with the proportions of land use and land cover in other large metropolitan areas (Abrams, 1965) as shown in table 11. Differences in the categories reflect the needs of different users. In many cases the differences are only those of scale and result from either the establishment or

TABLE 11.-Land use and land cover in selected cities [Adopted from Abrams (1965). Values expressed as a percentage of the total area of each cityl

\begin{tabular}{lrrrrr}
\hline \multicolumn{1}{c}{ Category } & Detroit & $\begin{array}{c}\text { Pitts- } \\
\text { burgh }\end{array}$ & $\begin{array}{c}\text { Phila- } \\
\text { delphia }\end{array}$ & $\begin{array}{c}\text { Cleve- } \\
\text { lanf }\end{array}$ & $\begin{array}{c}\text { Aver- } \\
\text { age }\end{array}$ \\
\hline Residential & 47.0 & 51.0 & 52.0 & 44.0 & 48.5 \\
Commercial & 2.6 & 1.8 & 4.2 & 4.9 & 3.4 \\
$\begin{array}{l}\text { Industrial \& } \\
\text { transportation }\end{array}$ & 9.3 & 9.0 & 11.8 & 9.0 & 9.8 \\
$\begin{array}{c}\text { Public rights- } \\
\text { of-way }\end{array}$ & 31.5 & 27.9 & 16.6 & 23.0 & 24.8 \\
$\begin{array}{c}\text { Institutional } \\
\begin{array}{c}\text { Open space \& } \\
\text { recreational }\end{array}\end{array}$ & 5.5 & 3.9 & 8.5 & 4.0 & 5.2 \\
\hline
\end{tabular}

aggregation of subclasses. Each of the land use and land cover systems in table 10 is discussed below.

\section{USGS LEVEL II SYSTEM}

The U.S. Geological Survey land use and land cover classification system is a two-level scheme, hierarchically designed to facilitate more detailed levels of categorization (Anderson and others, 1972 and 1976). Level $I$ is intended for use at extremely small scales and is too generalized to be applicable to this mesoscale problem. Level II categories are designed for use at a scale of approximately $1: 100,000$ and are similarly too generalized. A further categorization, extrapolated from Level II for use at larger scales, is introduced in the succeeding section. Hierarchically, these more detailed categories can be designated Level III.

Land use and land cover boundaries in Baltimore mapped at Level II are illustrated in figure 9. Sample strata of the study area are superimposed over the land use and land cover boundaries. Table 12 is a partial list of the 34 Level II land use and land cover categories defined by Anderson (1972). 


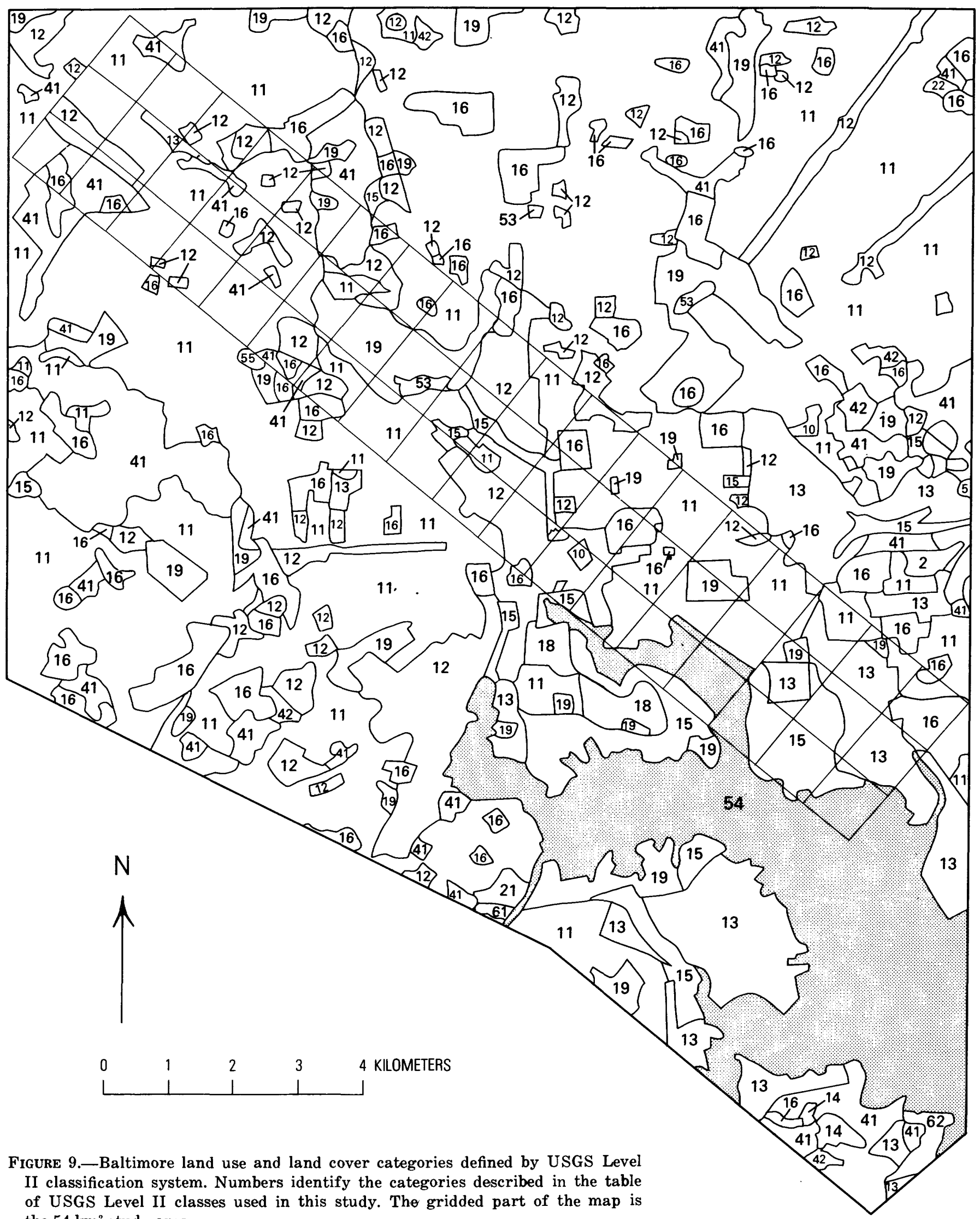

of USGS Level II classes used in this study. The gridded part of the map is the $54 \mathrm{~km}^{2}$ study area. 
TABLE 12.-USGS Level II land use and land cover classes applicable to this study

[Data from Anderson and others (1972)]

\begin{tabular}{|c|c|c|}
\hline (Level I: & $\begin{array}{r}1 \\
11 \\
12 \\
13 \\
14 \\
15 \\
16 \\
17 \\
18 \\
19\end{array}$ & $\begin{array}{l}\text { Urban \& Built-up Land) } \\
\text { Residential } \\
\text { Commercial \& Services } \\
\text { Industrial } \\
\text { Extractive } \\
\text { Transportation, Communications, \& } \\
\quad \text { Utilities } \\
\text { Institutional } \\
\text { Strip \& Clustered Settlement } \\
\text { Mixed } \\
\text { Open and Other }\end{array}$ \\
\hline (Level I: & $\begin{array}{r}2 \\
21 \\
22\end{array}$ & $\begin{array}{l}\text { Agricultural Land) } \\
\text { Cropland \& Pasture } \\
\text { Orchards, Groves, Bush Fruits, Vine- } \\
\quad \text { yards, \& Horticultural Areas }\end{array}$ \\
\hline (Level I: & $\begin{array}{r}4 \\
41 \\
42 \\
43\end{array}$ & $\begin{array}{l}\text { Forest Land) } \\
\text { Deciduous Forest } \\
\text { Evergreen Forest } \\
\text { Mixed Forest }\end{array}$ \\
\hline (Level I: & $\begin{array}{r}5 \\
51 \\
52 \\
53 \\
54\end{array}$ & $\begin{array}{l}\text { Water) } \\
\text { Streams \& Waterways } \\
\text { Lakes } \\
\text { Reservoirs } \\
\text { Bays \& Estuaries }\end{array}$ \\
\hline
\end{tabular}

Nine of these categories were identified within the Baltimore study area (table 12a). Physical, and thus aerodynamic, similarity between classes such
TABLE 12 a.-USGS Level II classes used in this study and their roughness lengths

\begin{tabular}{|c|c|c|c|}
\hline \multirow{2}{*}{\multicolumn{2}{|c|}{ Class (abbreviation) }} & \multicolumn{2}{|c|}{ Roughness length, $\mathrm{cm}$} \\
\hline & & Mean & Median \\
\hline 11 & Residential (RESID) & 100 & 88 \\
\hline 12 & $\begin{array}{l}\text { Commercial and Services } \\
\text { (COMML) }\end{array}$ & 181 & 107 \\
\hline 13 & Industrial (INDUS) & 52 & 36 \\
\hline 15,19 & $\begin{array}{l}\text { Transportation, Open and } \\
\text { Other (TRANS) }\end{array}$ & 47 & 29 \\
\hline 16 & Institutional (INSTI) & 130 & 62 \\
\hline 41 & $\begin{array}{l}\text { Deciduous Forest } \\
\text { (WOODS) }\end{array}$ & 117 & 106 \\
\hline 53,54 & $\begin{array}{l}\text { Reservoirs, Bays and } \\
\text { Estuaries (WATER) }\end{array}$ & 1 & 1 \\
\hline
\end{tabular}

as 53 and 54 (Reservoirs, Bays and Estuaries) permitted their integration and thereby reduced to. seven the number of categories used in this study.

\section{BALTIMORE ZONING ORDINANCE SYSTEM}

The most detailed land use and land cover system currently available for Baltimore is the Baltimore Zoning Ordinance (City of Baltimore, 1971) System. This system has four major categories: Residence (R), Office-Residence (OR), Business (B), and Industrial Districts (M). These categories are subdivided into 19 intermediate classes; for example, R-1, R-2, OR1 and OR2. Nonresidential classes are aggregated in a third level of the hier-

TABLE 13.-Baltimore Zoning Ordinance classes according to allowable gross building densities

\begin{tabular}{|c|c|c|c|c|}
\hline \multirow{2}{*}{$\begin{array}{l}\text { Combined } \\
\text { zoning } \\
\text { classes }\end{array}$} & \multirow{2}{*}{$\begin{array}{l}\text { Land use and land cover } \\
\text { zoning classes }\end{array}$} & \multirow{2}{*}{$\begin{array}{l}\text { No. of units } \\
\text { allowable }\end{array}$} & \multicolumn{2}{|c|}{$\begin{array}{c}\text { Sample } \\
\text { Roughness length, cm }\end{array}$} \\
\hline & & & Mean & Median \\
\hline \multicolumn{5}{|c|}{ Residence District: } \\
\hline R-12 & R-1 Single Family; R-2 General Residence & 6 & 70 & 60 \\
\hline $\mathbf{R}-\mathbf{3 4}$ & R-3 Single Family; R-4 General Residence & 9 & 78 & 72 \\
\hline R-50 & R-5 General Residence & 17 & 92 & 88 \\
\hline R-60 & R-6 General Residence & 29 & 95 & 69 \\
\hline $\mathbf{R}-\mathbf{7 0}$ & R-7 General Residence & 40 & 104 & 83 \\
\hline $\mathrm{R}-\mathbf{8 0}$ & R-8 General Residence & 58 & 121 & 106 \\
\hline \multicolumn{5}{|c|}{ Office-Residence District: } \\
\hline OR-29 & OR-2 Office-Residence; R-9 General Residence & 79 & 202 & 185 \\
\hline OR-34 & OR-3 and OR-4; Office-Residence & 218 & 324 & 275 \\
\hline \multicolumn{5}{|c|}{ Business District: } \\
\hline B-12 & B-1 Neighborhood; B-2 Community Business & $40-79$ & 108 & 76 \\
\hline B-30 & B-3 Community Commercial & $9-79$ & 119 & 47 \\
\hline B-45 & $=\mathrm{B}-4-1$ Central Business District; & & & \\
\hline & B-4-5 Central Commercial District & 363 & 293 & 148 \\
\hline \multicolumn{5}{|c|}{ Industrial District: } \\
\hline${ }^{1} \mathbf{M}-\mathbf{1 0}$ & M-10 Industrial, nuisance-free to adjoining & & & \\
\hline & Business or Residential & - & 84 & 73 \\
\hline${ }^{1} \mathbf{M}-20$ & M-20 Industrial, General Manufacturing and & & & \\
\hline & Industry, moderate nuisance characteristics & $-\ldots-$ & 54 & 49 \\
\hline${ }^{1} \mathbf{M}-\mathbf{3 0}$ & M-30 Industrial, heavy industry & --- & 51 & 38 \\
\hline
\end{tabular}


archy; for example, B-4-1, Central Business District, and B-4-5, Central Commercial District.

The Zoning Ordiance is meant to establish land use and land cover criteria that will help reduce overcrowding and congestion and thus enhance the health, safety, and services of the public. One of its major criterion is gross building density, a characteristic related to urban surface roughness. By aggregating those land use and land cover classes that have similar densities, the authors of this study formulated the 14 combined zoning classes listed in table 13.

\section{BALTIMORE LEVEL III SYSTEM}

Level III has not yet been formally developed in the U.S. Geological Survey land use and land cover hierarchy. Criteria for its use at meso- and microscales remain to be established by users. For regional planning activity-oriented functions must be emphasized when defining land use and land cover. But for climatological applications, the thermal, radiative, hydrologic, and aerodynamic properties of the surface must be accurately quantified. The Baltimore Level III system developed for this study constitutes a tentative land use and land cover classification system emphasizing morphological and physical characteristics. Thus, although the Baltimore Level III system is related to the USGS hierarchy, these urban morphology criteria have been devised for the experimental applications made during our research.

The basis for this Level III land use and land cover classification system is the differentiation of urban morphology using obstacle size and density as the principal criteria. As shown in table 14, the seven major categories of the Level III system are subdivided into 18 classes, which are described.

\section{SPATIAL DISTRIBUTION OF SURFACE ROUGHNESS IN THE STUDY AREA}

The areal distribution of surface roughness and the sample data for the study area are illustrated in figure $10 A, B$, and $C$. Use of the contouring option of the Synagraphic Computer Mapping Program (SYMAP) (Dudnick, 1971) provided an opportunity to compare visually the inferred roughness field with known land use and land cover distributions. This computer mapping program printed an index map depicting the 54 individual 1-km" cells of the study area in relation to the Baltimore City boundary (figure 10A). It also printed a map of surface roughness values corresponding to each 1$\mathrm{km}^{2}$ cell (figure $10 \mathrm{C}$ ). This map is divided into two
TABLE 14.-Baltimore Level III land use and land cover classes and their roughness lengths

[Developed for experimental application to an urban climate]

\begin{tabular}{|c|c|c|c|}
\hline & \multirow{2}{*}{ Class definition } & \multicolumn{2}{|c|}{$\begin{array}{c}\text { Sample } \\
\text { Roughness length, } \mathrm{cm}\end{array}$} \\
\hline & & Mean & Median \\
\hline \multicolumn{4}{|c|}{ Residential category: } \\
\hline RLD2 & $\begin{array}{l}\text { Low-density, up to two sto- } \\
\text { ries, single units }\end{array}$ & 38 & 39 \\
\hline RLD2W & $\begin{array}{l}\text { Same as RLD2 but with tree } \\
\text { rows }\end{array}$ & 76 & 73 \\
\hline RMD2 & $\begin{array}{l}\text { Medium-density, up to two } \\
\text { stories, multiple units }\end{array}$ & 73 & 71 \\
\hline RMD2W & $\begin{array}{l}\text { Same as RMD2 but with tree } \\
\text { rows }\end{array}$ & 120 & 86 \\
\hline RMD3 & $\begin{array}{l}\text { Medium density, up to three } \\
\text { stories, multiple units }\end{array}$ & 113 & 114 \\
\hline RMD3W & $\begin{array}{l}\text { Same as RMD3 but with tree } \\
\text { rows }\end{array}$ & 178 & 185 \\
\hline RMD4 & $\begin{array}{l}\text { Medium density, up to four } \\
\text { stories }\end{array}$ & 147 & 151 \\
\hline \multicolumn{4}{|c|}{ High-Rise category: } \\
\hline HR & $\begin{array}{l}\text { High-rise towers, five stories } \\
\text { or more; office, residential } \\
\text { or commercial, but not in- } \\
\text { stitutional or industrial }\end{array}$ & 481 & 322 \\
\hline \multicolumn{4}{|c|}{ Commercial category: } \\
\hline CLD & $\begin{array}{l}\text { Low density (plazas or equiv- } \\
\text { alent) }\end{array}$ & 11 & 11 \\
\hline CMD & $\begin{array}{l}\text { Medium density, up to four } \\
\text { stories }\end{array}$ & 87 & 78 \\
\hline \multicolumn{4}{|c|}{ Institutional category: } \\
\hline INST & $\begin{array}{l}\text { Institutional buildings (hos- } \\
\text { pitals, colleges) but does } \\
\text { not include land with vege- } \\
\text { tation (wooded or open) }\end{array}$ & 162 & 155 \\
\hline \multicolumn{4}{|c|}{ Industrial category: } \\
\hline ILD & $\begin{array}{l}\text { Low density, up to two sto- } \\
\text { ries; for example, ware- } \\
\text { houses }\end{array}$ & 28 & 28 \\
\hline IMD & $\begin{array}{l}\text { Medium density, up to four } \\
\text { stories }\end{array}$ & 78 & 82 \\
\hline IHD & $\begin{array}{l}\text { High density, over four } \\
\text { stories }\end{array}$ & 161 & 126 \\
\hline \multicolumn{4}{|c|}{ Open Areas category: } \\
\hline OPEN & $\begin{array}{l}\text { Water surfaces (lakes, bays) } \\
\text { or open land less than } 30 \\
\text { percent wooded }\end{array}$ & 7 & 8 \\
\hline \multicolumn{4}{|c|}{ Woodlands category: } \\
\hline & $\begin{array}{l}\text { Low density; for example, } \\
\text { widely spaced trees }\end{array}$ & 48 & 49 \\
\hline WMD & $\begin{array}{l}\text { Medium density; for exam- } \\
\text { ple, some clustering }\end{array}$ & 116 & 115 \\
\hline WHD & $\begin{array}{l}\text { High density; for example, } \\
\text { full forest }\end{array}$ & 246 & 260 \\
\hline
\end{tabular}

parts in order to show conveniently the entire study area on a single page. The location of sample points is shown by a printed surface roughness value. Additionally, the program produced a histogram of the mapped values (figure $10 B$ ).

The most distinctive regions on the contoured roughness map (fig. $10 \mathrm{C}$ ) are those with very high 
and very low values. That the lowest values, representing water surfaces, portray a realistic pattern of the inner harbor area can be seen by comparing cells A-03, A-04, and A-05 of the roughness map with the same cells on the Level II land use and land cover map in figure 9. The similarity verifies the adequacy of the sample distribution for representing a reasonable mesoscale pattern. The low values representing Druid Hill Lake in cell B-11, and Pimlico Racetrack in cell $\mathrm{C}-16$, are also revealed in the contoured roughness map.

The highest values, illustrated by class interval 10 (from fig. $10 B$ ) on the roughness map, identify the CBD and its peripheral clusters of high-rise buildings. Part of cell A-07 includes the northeastern half of the CBD and contains the highest value in the sample $(1,468 \mathrm{~cm})$.

The wide range of roughness values within cells A-08 and B-08 reflect a mixture of commercial, office-residential, and institutional complexes. The Level II land use and land cover map (fig. 9) shows some spatial correlation with the map of surface roughness (fig. $10 \mathrm{C}$ ) due to contrasts of land use and land cover in the cells of the roughness map.

An exception to the exclusive relation of higher values of roughness to the CBD and its periphery, is in cell A-01, which shows a roughness length of $557 \mathrm{~cm}$. Such an unexpectly high value identifies a grain elevator complex exceeding 300 meters in height. Field checks verified that this feature is a significant high-rise cluster in an area of otherwise low density buildup.

Elsewhere in the study area, intermediate ranges of roughness values are difficult to associate specifically with a given land use and land cover category. These values will be evaluated physically and statistically in following sections of this study.

\section{STATISTICAL ASSOCIATION BETWEEN LAND USE AND LAND COVER AND AERODYNAMIC ROUGHNESS}

Table 15 is a summary of the objectives and techniques employed in the statistical evaluation of the relation between land use and land cover and aerodynamic roughness. Each test in the table is numbered for reference to this study's discussion. In test 1 , each land use and land cover classification system was evaluated separately by use of the analysis of variance. This first test determined whether surface roughness could be used to distinguish differences between the classes of a given land use and land cover system. Test 2 was made to determine which land use and land cover classification system most efficiently discriminated between its classes. Test 3 repeated the analysis of variance, but with a nonparametric equivalent. The nonparametric version is an alternative requiring less rigorous assumptions about the form of the data. Once a land use and land cover system was found to possess class differences, test 4 permitted a pair-by-pair comparison to determine which particular classes were responsible for the differences.

In the first test, the null hypothesis of no difference between the surface roughness values of land use and land cover classes was tested by the oneway analysis of variance. This test was repeated for each of the three land use and land cover systems being evaluated, and each resulted in an $F$-statistic above the critical value at the 95-percent confidence level. The null hypothesis of no difference between means was, therefore, rejected. Test I shows the probability that some land use and land cover classes have significantly different surface roughness characteristics.

TABLE 15.-Statistical testing techniques used in land use and land cover analysis

\begin{tabular}{|c|c|c|c|c|}
\hline Test & Objective & Technique & Statistic & Method source \\
\hline 1 & $\begin{array}{l}\text { Test hypothesis of no dif- } \\
\text { ference between the class } \\
\text { means }\end{array}$ & $\begin{array}{l}\text { One-way analysis of variance (para- } \\
\text { metric) }\end{array}$ & $F$ & King, 1969 \\
\hline 2 & $\begin{array}{l}\text { Compare efficiency of land } \\
\text { use and land cover classi- } \\
\text { fication systems by pro- } \\
\text { portion of between-group } \\
\text { variance }\end{array}$ & $\begin{array}{l}\text { One-way analysis of variance (para- } \\
\text { metric) }\end{array}$ & $E$ & Dixon and Massey, 1969 \\
\hline 3 & $\begin{array}{l}\text { Test hypothesis of no differ- } \\
\text { ence between the class } \\
\text { means }\end{array}$ & $\begin{array}{l}\text { Kruskal-Wallis one-way analysis of vari- } \\
\text { ance (nonparametric) }\end{array}$ & $H_{l, w}$ & Siegel, 1956 \\
\hline 4 & $\begin{array}{l}\text { Determine which classes } \\
\text { have significantly differ- } \\
\text { ent means }\end{array}$ & $Q$-test & $D$ & Snedecor and Cochran, 1967 \\
\hline
\end{tabular}




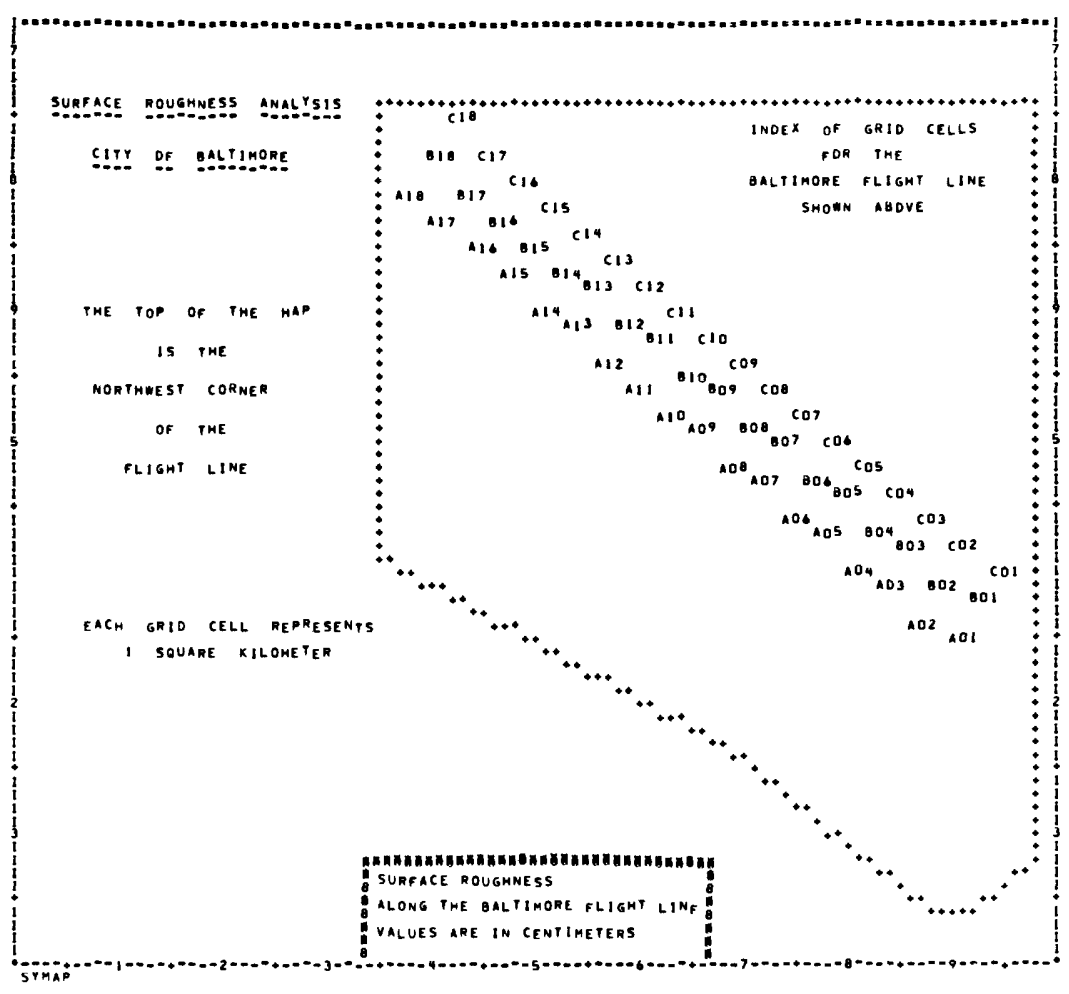

$A$

FIgURE 10.--Surface roughness in Baltimore study area. $A$ (above left), Index map of grid cell locations relative to Baltimore city boundaries; $B$ (below left), Frequency distribution of mapped surface roughness values; and $C$ (facing page), Contour map.

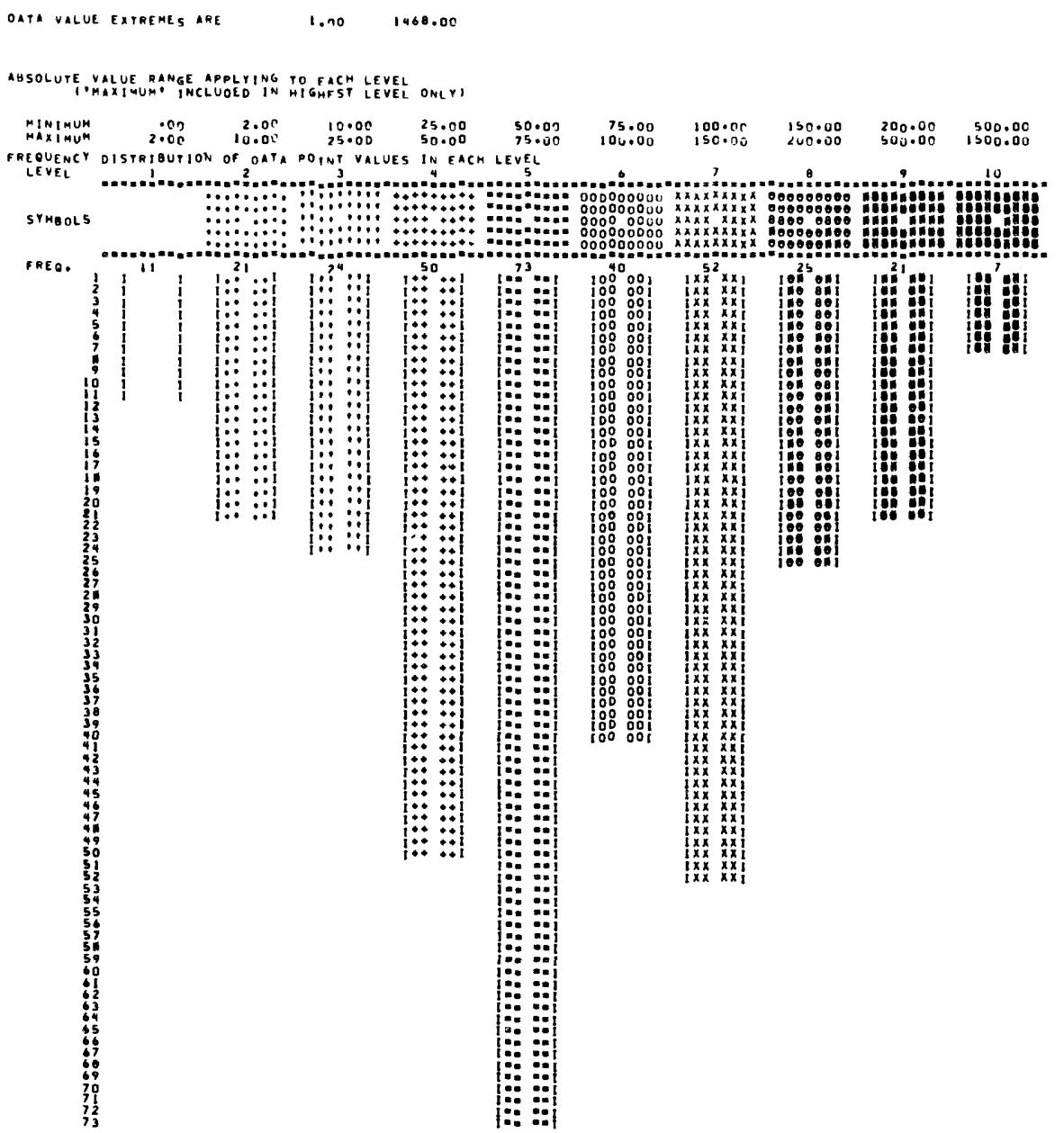




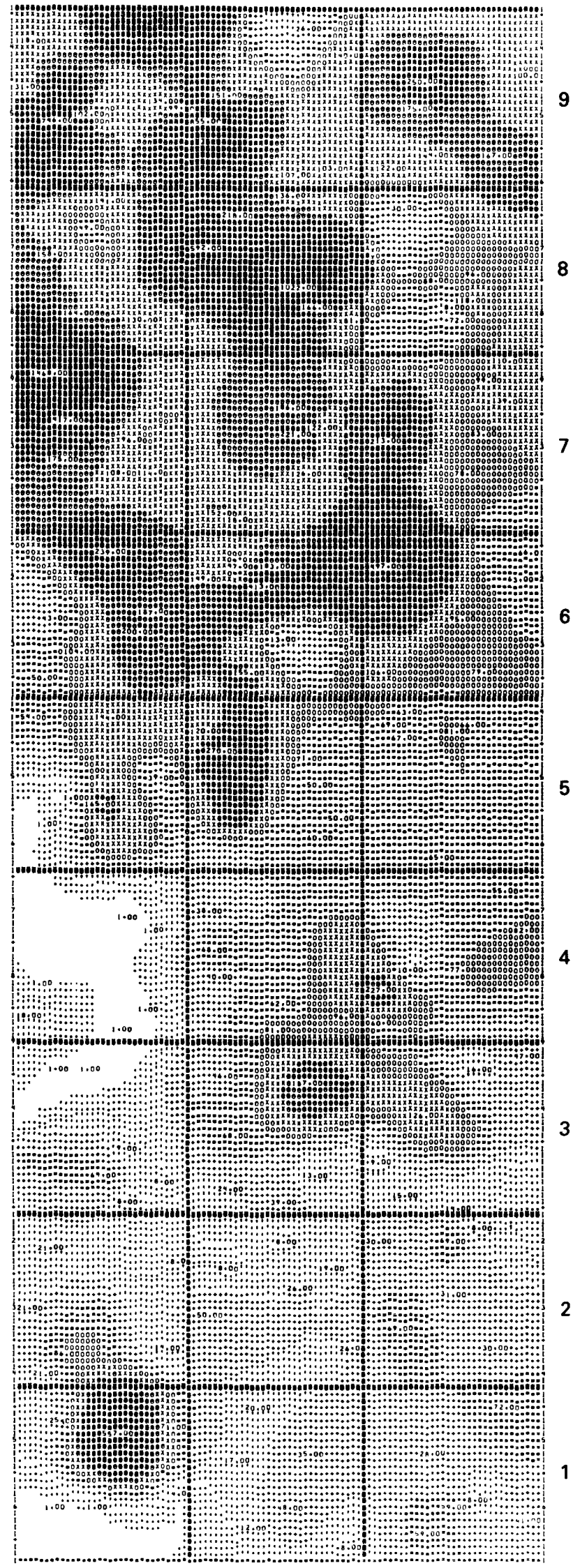

A

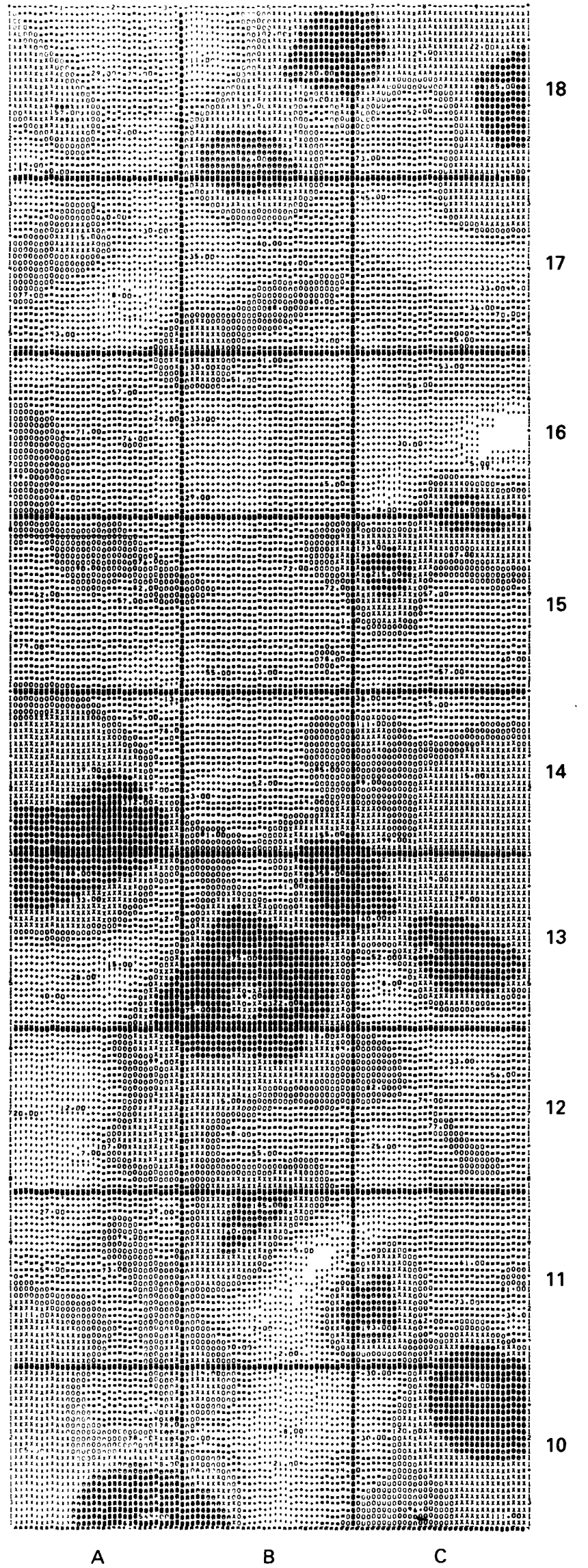


TABLE 16.-Comparison of the variance ratio for three land use and land cover systems

\begin{tabular}{lcc}
\hline \multicolumn{1}{c}{ Classification system } & $\begin{array}{c}\text { No. of } \\
\text { regions }\end{array}$ & $E$-statistic \\
\hline USGS Level II & 7 & 0.102 \\
Baltimore Zoning Ordinance & 14 & .166 \\
Baltimore Level III & 18 & .531 \\
\hline
\end{tabular}

The second test was used to compare the land use and land cover classification systems for their probable efficiency by calculating the $E$-statistic, or variance ratio-the ratio of the between-group variance estimate to the total variance estimate. A comparison of the $E$-statistic for each land use and land cover classification system is shown in table 16 in rank order. The Level II system showed the highest efficiency. The significance of this efficiency is evaluated separately for each land use and land cover system.

In evaluating the descriptive statistics, certain properties identified in the histogram of the sample set suggest a nonnormal distribution. Some nonnormal distributions represent a process rather than an unreliable sampling. Short-term precipitation, for example, may be characterized by a Poisson distribution (number of storms in a given time interval) or a Gamma distribution (precipitation amounts). However, since every assumption about the data may not have been rigorously met for the one-way analysis of variance, a nonparametric equivalent was performed. Computing the $H_{k w}$ statistic for the Kruskal-Wallis test, the critical value was exceeded at the 5-percent significance level for each land use and land cover system. Thus, the Kruskal-Wallis test, with an efficiency close to that of the more powerful $F$-test (Siegel, 1956), also showed that statistically significant differences exist between the mean surface roughness values in each system.

A final statistical analysis was made to determine which particular land use and land cover classes were creating the between-group difference indicated by the analysis of variance. A pair-by-pair comparison of the mean values of surface roughness requires that a "least significant difference" level be established. The literature, however, is not clear on the method for setting a statistically significant difference level. Regarding this matter, Downie and Heath (1959) state:

Suppose that an $F$-test had been significant. Should we then proceed and make a series of $t$-tests to see just what groups differ from each other? In the statistical literature there tends to be confusion on the answer to this question. In general, it appears that it is best not to. One might look at the various means and carry on further research using the observed differences that appear to be large enough to be significant.

Although Downie and Heath suggest the simple use of large observed differences in an evaluation, a least significant difference was used here to define a tentative boundary.

A critical value, $D$, is calculated using the square root of the within-group variance estimate, $s^{2}$, divided by the average number of observations, $N$, as follows :

$$
D=Q \sqrt{s^{2} / N}
$$

where $Q$ is the "Studentized Range" (Snedecor and Cochran, 1967) for a given significance level, in this case 5 percent. Having determined a critical $D$ value, differences between means of paired land use and land cover categories of each classification system may be statistically evaluated.

\section{USGS LEVEL II SYSTEM}

Table 17 shows that 7 of the 21 possible land use and land cover pairs of mean roughness values are significantly different. Statistical differences in the paired classes are apparently due to significant aerodynamic differences. The low aerodynamic properties of a smooth water surface, for example, are unlike those of all other land use and land cover classes except the industrial and transportation classes which generally contain large areas of open land.

Although the differentiation between land use and land cover classes of the USGS Level II scheme is relatively good, its small number of categories weakens the scheme's effectiveness for discriminating significant aerodynamic differences within some classes. The residential class (11), for example, may encompass up to half of the total urban land area

TABLE 17.-Differences between the paired means of roughness lengths of USGS Level II land use and land cover classes

[Values set in boldface type exceed the critical value of $D$, where $D=80.9$ ]

RESID COMML INDUS TRANS INSTI WATER WOODS

\begin{tabular}{lrrrrrrr} 
RESID & 0 & $\mathbf{8 1}$ & 48 & 53 & $\mathbf{3 0}$ & $\mathbf{9 9}$ & 17 \\
COMML & & 0 & $\mathbf{1 2 9}$ & $\mathbf{1 3 4}$ & $\mathbf{5 1}$ & $\mathbf{1 8 0}$ & 64 \\
INDUS & & & 0 & 5 & $\mathbf{7 9}$ & $\mathbf{5 1}$ & 65 \\
TRANS & & & & 0 & $\mathbf{8 3}$ & $\mathbf{4 6}$ & $\mathbf{7 0}$ \\
INSTI & & & & & 0 & $\mathbf{1 2 9}$ & 13 \\
WATER & & & & & & 0 & $\mathbf{1 1 6}$ \\
WOODS & & & & & & & 0 \\
\hline
\end{tabular}


TABLE 18.-Differences between the paired means of roughness lengths of Baltimore Zoning Ordinance classes [Land use and land cover symbols are defined in the table 13 listing Baltimore zoning classes. Va]ues set in boldface type exceed critical value $D$, where $D=130.41$

\begin{tabular}{|c|c|c|c|c|c|c|c|c|c|c|c|c|c|c|}
\hline & $\mathrm{R}-12$ & R-34 & $\mathrm{K}-50$ & $R-60$ & $\mathrm{R}-70$ & $\mathrm{R}-80$ & OR-29 & OR-34 & B-12 & B-30 & B- 45 & M-10 & M-20 & M-30 \\
\hline R-12 & 0 & 8 & 22 & 25 & 34 & 51 & 132 & 254 & 38 & 49 & 223 & 14 & 16 & 20 \\
\hline R-34 & & 0 & 14 & 17 & 26 & 43 & 124 & 246 & 30 & 41 & 215 & 6 & 24 & 28 \\
\hline R-50 & & & 0 & 3 & 12 & 29 & 110 & 232 & 16 & 27 & 201 & 8 & 38 & 42 \\
\hline$R-60$ & & & & 0 & 9 & 26 & 107 & 229 & 13 & 24 & 198 & 11 & 41 & 45 \\
\hline R-70 & & & & & 0 & 17 & 98 & 220 & 4 & 15 & 189 & 20 & 50 & 54 \\
\hline R-80 & & & & & & 0 & 81 & 203 & 13 & 2 & 172 & 37 & 67 & 71 \\
\hline OR-29 & & & & & & & 0 & 122 & 94 & 83 & 91 & 118 & 148 & 152 \\
\hline OR-34 & & & & & & & & 0 & 226 & 205 & 31 & 240 & 270 & 274 \\
\hline B-12 & & & & & & & & & 0 & 11 & 185 & 24 & 54 & 58 \\
\hline B-30 & & & & & & & & & & 0 & 174 & 35 & 65 & 69 \\
\hline B-45 & & & & & & & & & & & 0 & 209 & 239 & 243 \\
\hline M-10 & & & & & & & & & & & & 0 & 30 & 34 \\
\hline M-20 & & & & & & & & & & & & & 0 & 4 \\
\hline M-30 & & & & & & & & & & & & & & 0 \\
\hline
\end{tabular}

(tables 12 and 13). Moreover, this single residential class in the Level II scheme does not provide for differentiation of aerodynamic properties in the spectrum of building silhouette sizes and densities ranging from single-family residences to high-rise apartments. One advantage, however, of the USGS Level II land use and land cover system is its increasing applicability to a large number of national metropolitan areas (Wray, 1970; U.S. Geological Survey, 1977).

\section{BALTIMORE ZONING ORDINANGE SYSTEM}

The differences in paired mean roughness values for land use and land cover of the Baltimore Zoring Ordinance system are shown in table 18. Although the Baltimore system has twice the number of land use and land cover classes as the USGS Level II scheme, there is only a modest improvement in this zoning system's efficiency in discriminating aerodynamic roughness. This indicates that the discriminating effectiveness of the classification system is less related to the total number of categories used and more related to the characteristics of each individual category. The most obvious improvement demonstrated by the Baltimore system is the characterization of high-rise structures in zoning classes OR-34 and B-45. This small improvement over the USGS Level II classification system is supported by the higher between-group variance previously calculated in the $E$-statistics in table 16 .

Efficiency gained by the inclusion of land use and land cover classes describing high-rise buildings is somewhat offset by several other aspects of the Baltimore zoning system. The greater detail present in residential land use and land cover as divided into the six medium- and low-density subclasses still fails to distinguish significant differences in aerodynamic properties. Similarly, differentiation of industrial and commercial land into subclasses also fails to show significant statistical differences. Furthermore, the Baltimore system has no specific categories for woodlands or water areas, which would improve discrimination. Thus, despite its greater detail, the Baltimore Zoning Ordinance system does not appear to be significantly more applicable for determining aerodynamic differences than the USGS Level II classification system.

\section{BALTIMORE LEVEL III SYSTEM}

The Baltimore Level III classification system, formulated to differentiate land use and land cover classes according to obstacle height and density has those 18 classes paired by differences in mean values (table 19). The relatively large number of pairs showing significantly different mean values verifies this system's improved discrimination of surface roughness. This improvement is supported by the high value of between-group variance to total variance shown by the calculated $E$-statistic in table 16 .

The differences between the paired means of the roughness lengths of the classes in table 19 may first be compared with the expected differences in roughness between open areas with relatively smooth surfaces and areas with the roughest surfaces. The values of the relatively open areas (OPEN) are significantly different from those of the most aerodynamically rough areas, that is highrise (HR) and high-density woodlands (WHD). Further statistical discrimination is noted between open areas and some classes of land use and land cover of intermediate roughness, including threestory residential-wooded (RMD3W), four-story residential (RMD4), institutional buildings (INST), and industrial high-density (IHD). 
TABLE 19.-Differences between the paired means of roughness lengths of Baltimore Level III land use and land cover classes

[Land use and land cover symbols defined in the table 14 listing. Values in boldface type exceed critical value $D$, where $D=112.4$ ]

\begin{tabular}{|c|c|c|c|c|c|c|c|c|c|c|c|c|c|c|c|c|c|c|}
\hline & 令 & 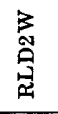 & 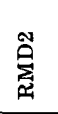 & 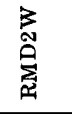 & 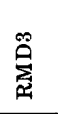 & 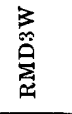 & 芦 & 荬 & 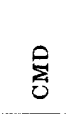 & 今્ & 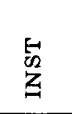 & 量 & 主 & 思 & $\begin{array}{l}\text { z } \\
\text { 空 } \\
\text { 口. }\end{array}$ & 品 & 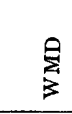 & 思 \\
\hline RLD2 & 0 & 38 & 35 & 82 & 75 & 140 & 109 & 443 & 49 & 28 & 124 & 10 & 40 & 124 & 31 & 10 & 78 & 207 \\
\hline RLD2W & & 0 & 3 & 44 & 37 & 102 & 71 & 405 & 11 & 65 & 86 & 48 & 2 & 86 & 69 & 28 & 40 & 169 \\
\hline RMD2 & & & & 47 & 40 & 105 & 74 & 408 & 14 & 62 & 89 & 45 & 5 & 89 & 66 & 25 & 43 & 172 \\
\hline RMD2W & & & & 0 & 9 & 58 & 27 & 361 & 33 & 109 & 42 & 92 & 42 & 42 & 113 & 72 & 4 & 125 \\
\hline RMD3 & & & & & 0 & 65 & 34 & 368 & 26 & 102 & 49 & 85 & 35 & 49 & 106 & 65 & 3 & 132 \\
\hline RMD3W & & & & & & 0 & 31 & 303 & 91 & 167 & 16 & $\begin{array}{r}150 \\
\text { D }\end{array}$ & 100 & 16 & 171 & 130 & 62 & 67 \\
\hline RMD4 & & & & & & & 0 & 334 & 60 & 136 & 15 & 119 & 69 & 15 & 140 & 99 & 31 & 98 \\
\hline HR & & & & & & & & 0 & 394 & 470 & 319 & 453 & 403 & 319 & 474 & 433 & 365 & 245 \\
\hline CMD & & & & & & & & & 0 & 76 & 75 & 59 & 9 & 75 & 80 & 39 & 29 & 158 \\
\hline CLD & & & & & & & & & & 0 & 151 & 17 & 67 & 151 & 4 & 37 & 105 & 234 \\
\hline INST & & & & & & & & & & & 0 & 134 & 84 & 0 & 155 & 114 & 46 & 83 \\
\hline ILD & & & & & & & & & & & & 0 & 50 & 134 & 21 & 20 & 88 & 217 \\
\hline IMD & & & & & & & & & & & & & 0 & 84 & 71 & 30 & 38 & 167 \\
\hline IHD & & & & & & & & & & & & & & 0 & 155 & 114 & 46 & 83 \\
\hline OPEN & & & & & & & & & & & & & & & 0 & 41 & 109 & 238 \\
\hline WLD & & & & & & & & & & & & & & & & 0 & 68 & 197 \\
\hline WMD & & & & & & & & & & & & & & & & & 0 & 129 \\
\hline WHD & & & & & & & & & & & & & & & & & & 0 \\
\hline
\end{tabular}

Classes with the roughest surfaces, HR and WHD, show significant differences in value when compared with those in most of the other land use and land cover classes. The exceptions occur when a land use and land cover category is characterized by a roughness value similar to the value with which it is paired. The roughness characteristics of high-density woodlands, for example, are not significantly different from those of groups of the highest buildings-that is, medium-density three-story and fourstory buildings, and high-rise buildings.

The roughness values of some land use and land cover categories that include buildings of intermediate height and are of intermediate building density do not differ significantly from each other. The roughness values of low-density residential areas are not significantly different from those of medium-density residential areas unless the mediumdensity class contains three-story buildings and treelined streets. For example, the differences in surface roughness between the RMD3W and the other residential classes suggest that residential land need not be differentiated into more than two classes, with the change from low- to medium-density residential areas made beginning at the RMD3W class. The HR class, consisting of high-rise office and residential buildings five or more stories high, can be very easily discriminated without modification from the other classes.

The roughness values of land use and land cover categories in the middle portion of the spectrum of mean roughness values overlap those of their neigh- bors. For example, the medium-density industrial class shows significant contrast only with the classes that are the roughest aerodynamically: HR and WHD. The mean roughness values of the low-density industrial class, however, differ significantly from those of four other land use and land cover categories: RMD3W, RMD4, INST, and OPEN. Because land use and land cover categories with intermediate mean roughness values are difficult to sort out and interpret, further evaluation of them is deferred until their physical response is measured by numerical simulation of the surface climate.

\section{THE CBD AS A UNIOUE LAND USE AND LAND COVER GLASS}

The CBD has been characterized in the earlier section on statistical description and analysis as a unique part of the sample. This uniqueness is evident from the exceptionally high surface roughness values associated with high-rise buildings in the CBD and the expected strong influence by increased turbulent transfer on the surface energy balance. Part of the CBD is identified on the surface roughness map in figure $10 C$ by the high values occurring in portions of cells A-07, B-08, A-09, and B-09. These high values are distributed over approximately 5 percent of the study area.

In spite of the relatively small size of the CBD within the city, several factors justify further attention regarding the use of this area as an independent land use and land cover class. First, in Baltimore as in most cities high-rise buildings typi- 
cally occur interspersed with relatively low buildings, rather than as a continuous field of high structures. Sample values are, therefore, especially sensitive to the particular building compositions of individual plots. More detailed measurements are needed to verify the accuracy of the small CBD sample. Secondly, the skyscraper portion of the Baltimore CBD is undergoing rapid growth with continued expansion projected into the coming decade. A significant part of the Metro-Center Technical Study and Comprehensive Plan (Wallace and others, 1970) is already a reality for the Baltimore inner harbor area. Finally, knowledge of the surface roughness characteristics of the Baltimore CBD may be useful for making better estimates of the surface roughness of metropolitan centers elsewhere, especially those possessing larger central business districts.

To verify the reliability of the previous sampling of the CBD area, surface roughness is calculated for a complete population of roughness elements within the central core of the district. This defined CBD core area is approximately $0.7 \mathrm{~km}^{2}$ and is divided into the 12 plots shown in figure 11. Plot identification numbers are the Sanborn map page numbers from which building dimensions were acquired. The average plot size is 5.7 ha. The average roughness length for each plot is also contained in the figure.

In table 20 a list of building height, roughness length, and silhouette ratio for each CBD areal plot, is presented, where the silhouette ratio is a density index taken from the Lettau formula (eq. 4): High silhouette ratios must be accompanied by significant building heights to produce higher surface roughness values. The highest roughness length, $2,118 \mathrm{~cm}$, ap-

TABLE 20.-Aerodynamic roughness characteristics of the Baltimore $C B D$

\begin{tabular}{|c|c|c|c|c|}
\hline \multirow[b]{2}{*}{$\begin{array}{l}\text { No. of } \\
\text { CBD plot }\end{array}$} & \multicolumn{2}{|c|}{ No. of stories } & \multicolumn{2}{|c|}{ Aerodynamic values } \\
\hline & $\begin{array}{c}\text { Highest } \\
3 \\
\text { buildings }\end{array}$ & $\begin{array}{c}\text { Plot } \\
\text { average }\end{array}$ & $\begin{array}{l}\text { Roughness } \\
\text { length } \\
\text { (cm) }\end{array}$ & $\begin{array}{c}\text { Silhouette } \\
\text { ratio }\end{array}$ \\
\hline 22A & $7,7,6$ & 4 & 226 & 0.29 \\
\hline 23A & $20,12,12$ & 7 & 1,468 & 0.65 \\
\hline 24A & $8,6,4$ & 4 & 167 & 0.21 \\
\hline $25 A$ & $9,5,3$ & 4 & 136 & 0.14 \\
\hline 32A & $30,27,22$ & 14 & 1,617 & 0.47 \\
\hline 33A & $37,28,28$ & 10 & 1,631 & 0.54 \\
\hline 34A & $18,14,13$ & 8 & 640 & 0.38 \\
\hline $35 \mathrm{~A}$ & $4,3,2$ & 3 & 51 & 0.09 \\
\hline $42 A$ & $21,14,14$ & 7 & 707 & 0.29 \\
\hline 43A & $30,22,21$ & 12 & 2,118 & 0.90 \\
\hline 44A & $15,12,10$ & 8 & 933 & 9.51 \\
\hline $\mathbf{4 5 A}$ & $8,5,5$ & 5 & 195 & 0.21 \\
\hline TOTAL & $37,30,30$ & 8 & 673 & 0.39 \\
\hline
\end{tabular}

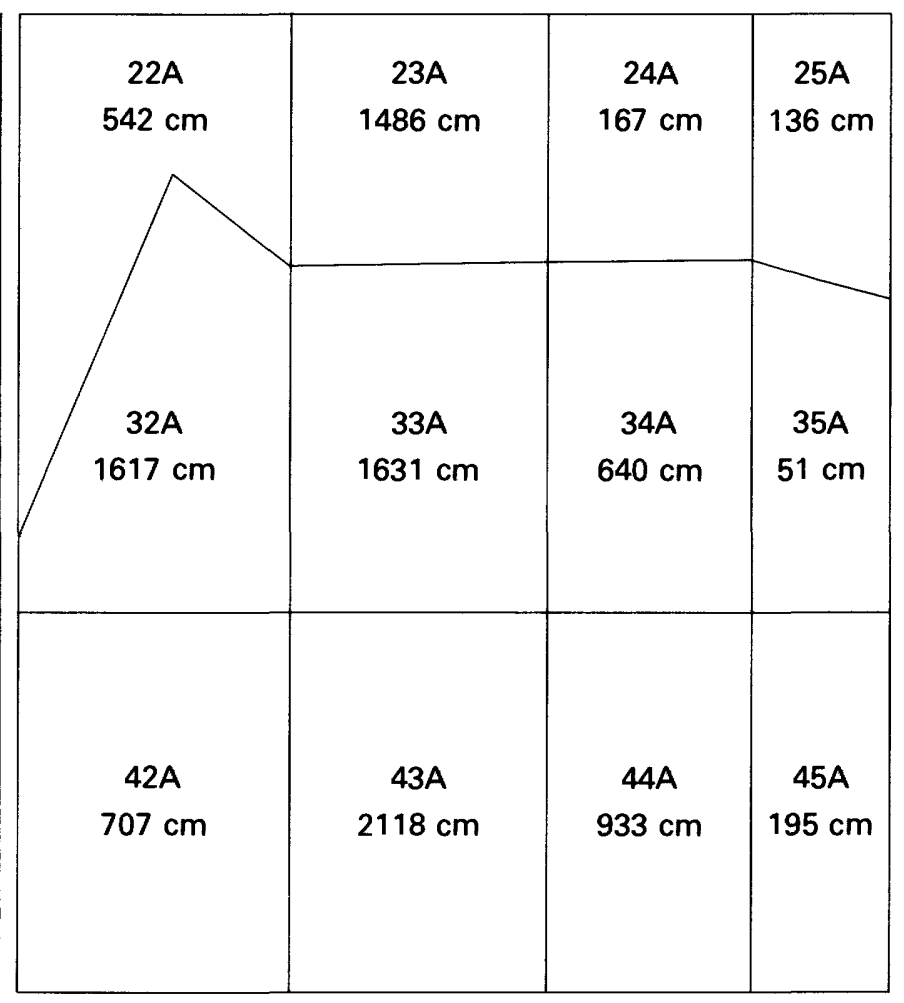

FiguRe 11.-Distribution of surface roughness values, in centimeters, in the core area of the Baltimore central business district (CBD). The core area is divided into 12 plots, each designated by a Sanborn map page number.

pears in plot 43A. Viewed from the south, this plot contains the largest buildings in the middle section of the CBD including the Maryland National Bank Building, and the recently constructed U.S. Fidelity $\&$ Guaranty Building. Buildings in plot $43 \mathrm{~A}$ average 12 stories, although four buildings exceed 20 stories in height and another three buildings are over 12 stories high. Plots $32 \mathrm{~A}$ and $33 \mathrm{~A}$ have taller buildings but their heights are offset by the larger silhouette ratio in plot $43 \mathrm{~A}$. Plots on the eastern side of the CBD core area have the lowest roughness lengths, with plot 35A having a value of only $51 \mathrm{~cm}$. This peripheral area has low buildings (three stories) and considerable open land. This side of the CBD has a more abrupt transition between high- and low-density commercial land use and land cover.

This evaluation shows that surface roughness has a relatively high absolute range of values across the CBD and varies according to the composition of building heights, densities, and silhouette ratios. Where high-rise buildings are tightly clustered, the high roughness values may be overestimated because cluster shielding reduces silhouette exposures. 
Conversely, values for open areas within the CBD may be underestimated because of their location in the downstream path of turbulence induced from neighboring high-rise buildings. The mean roughness length for the entire population of obstacles, $824 \mathrm{~cm}$, appears to be a reasonable mesoscale estimate for the overall CBD core area. Estimates of the roughness length for high-rise buildings, however, represent the extension of an empirical expression that is difficult to evaluate physically (Monteith, 1973).

\section{LAND USE AND LAND COVER CLASSES RANKED BY} MEAN ROUGHNESS LENGTHS

Mean roughness lengths were used to rank land use and land cover classes within each of the three systems described in this paper. The rankings for the three systems are compared in figure 12. The position of each class within the spectrum of surface roughness values shows the resolution of each classification system in relation to the others. In addition to resolution-the sensitivity of each system to variations in roughness length-the efficiency and economy of classification effort is also suggested by the ranking of the classes. The degree of efficiency and economy is derived by determining the availability of data needed for a particular land use and land cover classification system and the number of land use and land cover classes contained in that system.

The seven categories of the USGS Level II classification system give a conservative estimate of the aerodynamic properties of land use and land cover. The ranked distribution of values (fig. 12) generally agrees with the physical character of the classes. The roughness values for Level II are conservative because a wide range of differences is masked in the averaging process. Small modifications to this classification system would greatly enhance its potential for distinguishing physical properties without adding undue complexity to its structure. In particular, a separate class to identify highrise structures, regardless of activity function, could be incorporated into the system without difficulty.

Another important shortcoming of the Level II system is the absence of subclasses in the residential land use and land cover category. Resolution would be greatly improved by a simple two-fold division between high- and low-density classes. Wray (1973) successfully applied such a modification to the USGS Level II system by dividing residential land into single- and multiple-family categories, thereby increasing the applicability of the system.

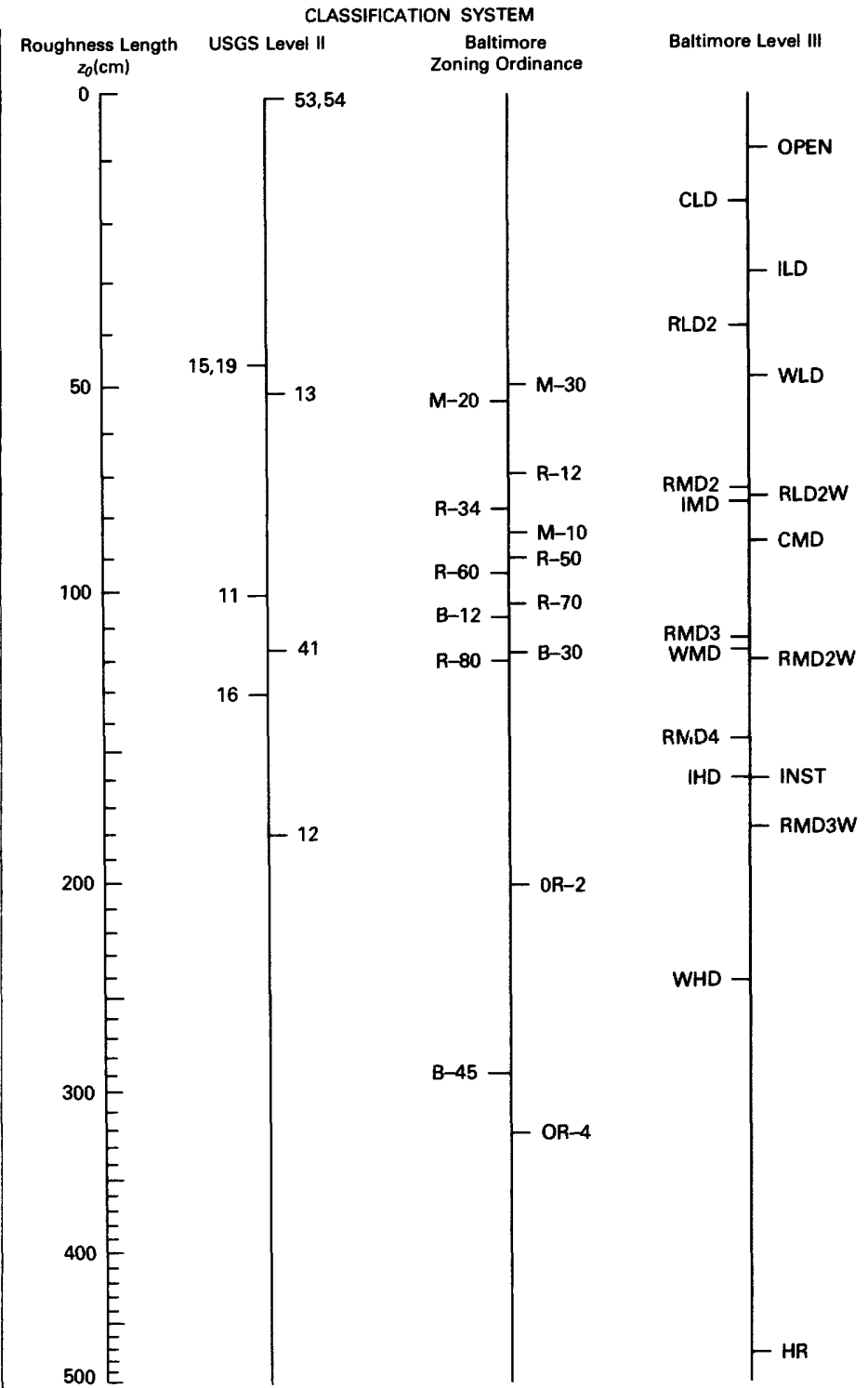

Figure 12.-Land use and land cover classes ranked by mean values of surface roughness. The symbols for land use and land cover categories of the three classification systems used are listed in the tables describing these systems.

The Baltimore Zoning Ordinance classification system, with its 14 land use and land cover classes, shows only modest improvement over the Level II classification system in the resolution of features related to surface roughness. It does not account for high-rise buildings in the office-residential classes (OR-2, OR-4), but includes a category for the CBD $(\mathrm{B}-45)$. The six residential classes do not clearly distinguish known differences in building densities. The surface roughness values of these six classes are distributed closely around the central value derived for the Level II residential class. In general, the economy of the classification effort is lost in the large number of categories in the zoning system. 
The Baltimore Level III land use and land cover system, as compared with the others in figure 12, shows the best resolution in differentiating roughness length. It also demonstrates a stronger relationship with certain physical characteristics than schemes that employ strict activity function criteria in land use and land cover classification. Residential, commercial, and industrial classes show a general quantitative increase along the spectrum of values according to physical characteristics; for example, low, medium, and high densities of development. Low-density commercial land, representing large open shopping plazas, is similar aerodynamically to such land use and land cover categories as open and low-density industrial land. Clusters of high-rise buildings represent a distinctive class regardless of activity function, since residential, commercial, and institutional high-rise buildings have similar physical properties.

A comparison of the three land use and land cover classification systems evaluated herein shows the Baltimore Level III system to possess the best resolution and agreement with the physical properties of land use and land cover in a given class. It is not, however, a system widely used in mapping. The Level III system requires the prospective user to generate a land use and land cover classification for his region, a task beyond the capability of many investigators. The chief value of Level III lies in its resolution, but that superior resolution may be offset by economic considerations. The Baltimore Zoning Ordinance System has demonstrated some value for mapping land use and land cover but suffers from the redundancy of certain land use and land cover categories. In addition, its zoning boundaries are not established according to a universal set of criteria. On the other hand, wherever Level II mapping has been done the USGS Level II system, with the suggested modifications, may be used immediately.

\section{EVALUATION OF AERODYNAMIC ROUGHNESS BY SIMULATION MODELING OF SURFACE CLIMATE}

Energy balance simulation models are increasingly being used in climatology to study the interrelationships between meteorological conditions and the physical character of the surface. Theoretical models of energy transfer through the Earth-atmosphere interface were developed relatively early (Brunt, 1934, Lettau, 1951). Hardware was eventually developed to model the effects of the essential atmospheric and surface parameters. Halstead and others
(1957) pioneered a sophisticated physical-numerical analog simulator that was the basis for later versions (Appleby and Fujikado, 1960; Estoque, 1963) adapted to high-speed computer operations. Myrup (1969) introduced an analog simulation model for urban climate applications that was based on the work of Halstead and others (1957). Myrup's model was recently modified by Outcalt (1972a) for use with a digital computer. The Outcalt version is employed in this study to evaluate the physical association between land use and land cover and surface roughness.

The Outcalt numerical model is one version of the computer software designed for researching surface climate problems. It has evolved from the theoretical models previously cited, but it has design characteristics that make it relatively easy to simulate changes in surface boundary parameters. The Outcalt model is based on energy conservation principles and uses time-dependent equations to estimate energy fluxes in response to a specified set of atmospheric and surface conditions. The solution to the energy balance conservation equations is based upon equilibrium temperature theory, which allows a single surface temperature to be used for convergence with the observed thermal regime (Outcalt, 1972a). No attempt is made here to discuss the computational details of the model, which are fully described in Myrup (1969) and Outcalt (1972a).

This analysis deals with changes to energy flux parameters as a response to differences in surface roughness. To activate the numerical simulator, the boundary conditions shown in table 21 are specified.

TABLE 21.-Input data (boundary conditions) for the numerical simulation experiment

[Data for Baltimore, Md., on May 11, 1972 ]

1. Temporal data:

Latitude

$39.9^{\circ}$

Solar declination

Radius vector of Earth orbit

$17.7^{\circ}$

1.010149

2. Meteorological data:

Sky radiant temperature

Atmospheric dust content

Mean diurnal air temperature

Wind velocity

Air relative humidity fraction

Precipitable water

Station pressure

$-17^{\circ} \mathrm{C}$

1 particle $\mathrm{cm}^{-3}$

$5^{\circ} \mathrm{C}$

$100 \mathrm{~cm} \mathrm{sec}^{-1}$

0.40

$10 \mathrm{~mm}$

$1007 \mathrm{mb}$

3. Geographic data:

Soil volumetric heat capacity $\quad 0.5 \mathrm{cal} \mathrm{cm} \mathrm{cm}^{-3}{ }^{\circ} \mathrm{C}^{-1}$

Soil thermal diffusivity

Surface albedo fraction

Surface wet fraction

Shadow ratio

$0.02 \mathrm{cal} \mathrm{cm}^{-1}{ }^{\circ} \mathrm{C}^{-1}$

0.22

$0.25 \& 0.01$

0.15

Surface roughness

$1-2000 \mathrm{~cm}$

Source: Outcalt, 1972a 
These conditions were determined from ground observations acquired during a remote sensing experiment flown over Baltimore on May 11, 1972 (Pease and others, 1976).

Input data are organized into three categories: temporal, meteorological, and geographic. Temporal data are a function of latitude and time of year. The meteorological data represent average atmospheric conditions for the date specified. The geographic data are, as hypothesized, functions of land use and land cover. Attention is directed specifically to the sensitivity of the energy balance to changes in surface roughness. Output from the model consists of hourly values of solar radiation components, surface energy transfers, and a soil temperature matrix. The changes to the surface energy balance transfers induced by surface roughness are evaluted by the energy conservation equation.

$$
R_{n}+H+L+S=0
$$

where $R_{n}$ is the sum of net radiation, $H$ is the sensible heat flux to the atmosphere, $L$ is the latent heat flux, and $S$ is the soil heat flux (table 22). The effects of surface roughness on surface radiant temperatures $(T)$ are also evaluated.

\section{SENSITIVITY TESTING}

The previous statistical evaluation demonstrates that the Baltimore Level III system is the most discriminating land use and land cover system in its characterization of surface roughness by land use and land cover class. This discrimination is evident in the ranking of land use and land cover categories for the three systems we compared (fig. 12). The USGS Level II system is a conservative generalization of a small number of land use and land cover types. Although the Baltimore Zoning Ordinance

TABLE 22.-Output data from numerical simulation model [All data in millilangleys/min., except $T={ }^{\circ} \mathrm{C}$ ]

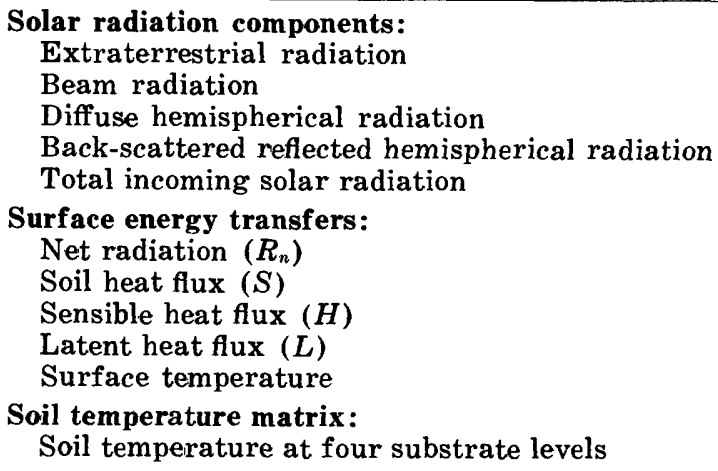

Source: Outcalt, 1972a
TABLE 23.-Values of the energy balance components simulated for Baltimore

[Values for solar noon. Surface wet fraction $=0.25$ ]

\begin{tabular}{rrrrr}
\hline $\begin{array}{c}z_{o} \\
(\mathrm{~cm})\end{array}$ & $S$ & $H$ & $L$ & $\begin{array}{c}\boldsymbol{T} \\
\left({ }^{\circ} \mathrm{C}\right)\end{array}$ \\
\cline { 2 - 4 } & \multicolumn{3}{c}{ (millilangleys/min.) } & 28.9 \\
8 & 484 & 294 & 183 & 25.7 \\
55 & 421 & 354 & 207 & 23.3 \\
75 & 374 & 398 & 224 & 21.7 \\
100 & 343 & 426 & 236 & 20.1 \\
125 & 311 & 454 & 249 & 18.9 \\
150 & 288 & 474 & 259 & 18.1 \\
175 & 273 & 487 & 267 & 17.1 \\
200 & 252 & 503 & 277 & 16.4 \\
225 & 238 & 513 & 284 & 15.8 \\
250 & 227 & 521 & 291 & 15.0 \\
275 & 212 & 530 & 301 & 14.3 \\
300 & 198 & 538 & 311 & 14.1 \\
325 & 194 & 539 & 314 & 13.5 \\
350 & 182 & 545 & 324 & 13.0 \\
\hline
\end{tabular}

classification system differentiates a wider range of categories, only the high-rise category described by zoning classes OR-2, OR-4, and B-45 provides for greater discrimination than Level II. The sensitivity test described below, therefore, makes use of the range of roughness values representative of the Level III classification system. In addition, values for the CBD, an area possessing unique land use and land cover features, are tested separately.

\section{SIMULATION OF BALTIMORE LEVEL III SYSTEM VALUES}

The simulated surface energy balance components for increments of roughness lengths are shown in Table 23. The response to increasing amounts of surface roughness shows changes in the expected direction. As turbulent transfer becomes more pronounced with increased roughening, the latent and sensible heat fluxes increase. This increase depletes the available surface energy, thereby reducing the surface radiant temperature and the soil heat flux downward during the mid-day energy regime shown in figure 13.

The linear progression of increasing roughness lengths clearly shows the rate at which the energy flux decreases. The lower roughness values have a disproportionate influence on the partitioning of the components of net radiation, or available energy. For example, roughness lengths up to $125 \mathrm{~cm}$ have a much greater effect on the sensible heat flux, than an equivalent change in the higher roughness values. The general trend in the model is a decreasing response in energy transfer to a linear increase in surface roughness. This trend matches the log- 


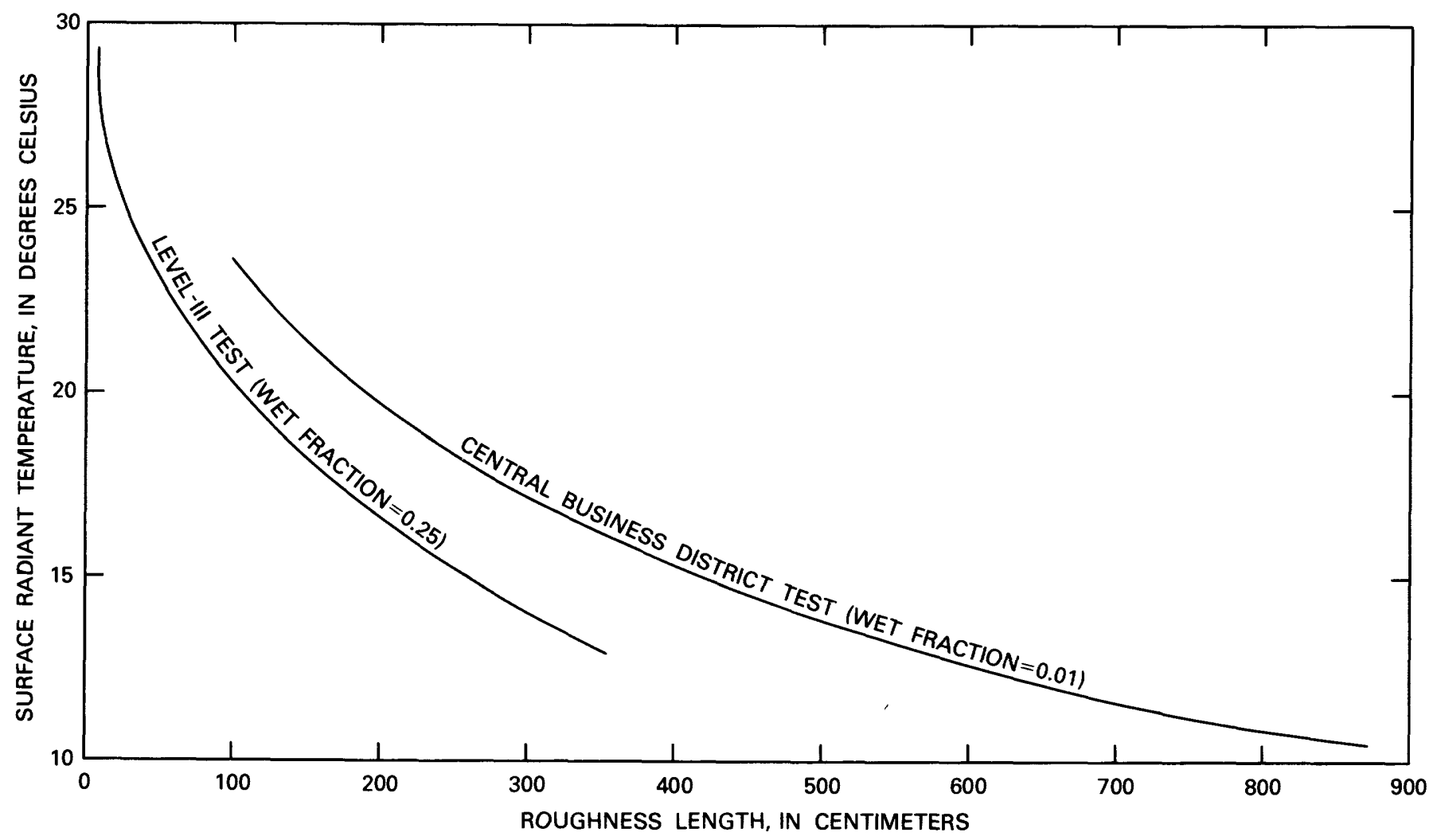

Figure 13.--Surface temperature as a function of roughness length.

arithmic form of the wind profile equation in the simulation model. This energy balance simulation demonstrates that a more accurate estimate of aerodynamic roughness is warranted for land use and land cover at the lower range of roughness values.

\section{SIMULATION OF GBD VALUES}

Two important parameters influence the energy balance components for the unique case of the CBD. Exceptionally high surface roughness values are generated by the geometry of high-rise building clusters. An additional surface parameter that has great influence on the energy balance is the evaporation area, which is significantly reduced. Depriving the surface of its evaporation opportunity forces much more of the available energy into sensible heating of the soil and overlying atmosphere. For simulation purposes, the surface wet fraction of 0.25 for urban land use and land cover is changed to 0.01 to reflect more accurately the hydrologic character of the CBD.

The simulated surface energy balance components for the CBD are shown in table 24. The range of roughness lengths and the larger incremental steps listed in this table, as opposed to those in table 25, are representative of estimates derived from the
TABLE 24.--Values of the energy balance components simulated for the Baltimore $C B D$

[Values for solar noon. Surface wet fraction $=0.01$ ]

\begin{tabular}{rrrrr}
\hline $\begin{array}{c}z_{\sigma} \\
(\mathrm{cm})\end{array}$ & $S$ & \multicolumn{1}{c}{$H$} & $L$ & $\begin{array}{c}T \\
\left({ }^{\circ} \mathrm{C}\right)\end{array}$ \\
\cline { 2 - 3 } 100 & 410 & 570 & 13 & 23.6 \\
200 & 322 & 679 & 15 & 19.8 \\
300 & 267 & 745 & 16 & 17.4 \\
400 & 223 & 798 & 18 & 15.5 \\
500 & 190 & 839 & 20 & 14.0 \\
600 & 164 & 870 & 21 & 12.8 \\
700 & 142 & 884 & 23 & 11.9 \\
800 & 124 & 913 & 25 & 11.1 \\
900 & 110 & 930 & 27 & 10.4 \\
1000 & 98 & 943 & 30 & 9.9 \\
1100 & 87 & 953 & 32 & 9.4 \\
1200 & 78 & 962 & 35 & 8.9 \\
1300 & 70 & 969 & 38 & 8.6 \\
1400 & 63 & 974 & 41 & 8.2 \\
1500 & 57 & 978 & 44 & 8.0 \\
1600 & 52 & 981 & 48 & 7.7 \\
1700 & 47 & 982 & 52 & 7.5 \\
1800 & 43 & 983 & 57 & 7.2 \\
1900 & 39 & 983 & 62 & 7.1 \\
2000 & 36 & 982 & 66 & 7.0 \\
\hline
\end{tabular}

evaluation of the unique CBD data set. The latent heat component is virtually eliminated from the energy partitioning due to the small wet fraction. The soil heat flux diminishes rapidly as the rough- 
ness length increases to exceptionally high valuesof $500 \mathrm{~cm}$ or greater. Beyond this value the estimate for the roughness length becomes unrealistically large, and a meteorological assessment of such a condition is difficult.

The trend of values of the energy balance components for the lower range of roughness lengths in table 26, however, is valid with regard to the competing physical processes. With the sensible heat flux as a measure of the impact of roughness on turbulent transfer, the lower range of roughness lengths shows the expected disproportionate influence. For example, the effect of a $100-\mathrm{cm}$ increase in roughness length on the sensible heat flux at the beginning of the test has a greater effect than a $1,000-\mathrm{cm}$ change at the high end of the roughness length scale. The high sensitivity of the values of the energy balance components to increments in the small values of the roughness length underscores the importance of accurately estimating aerodynamic surface properties.

\section{APPLICATIONS OF LAND USE AND LAND COVER INFORMATION IN URBAN CLIMATOLOGY}

This study has described a methodology for estimating surface roughness by the Lettau model (eq. 4). Physical similarity theory enables this empirical formula to be used to determine surface roughness from a description of the wind obstacles. This indirect approach to determining aerodynamic roughness for numerous types of urban land use and land cover is presently the only alternative to the difficult determination of surface roughness from wind profile measurements in areas of complex urban buildup.

The statistical analysis of the 324 roughness samples identified by the USGS Level II and the Baltimore Level III land use and land cover systems suggests that reasonable estimates of surface roughness can be made at two mesoscale levels. Statistics for the Level II and Level III systems are summarized in tables 25 and 26, respectively. The USGS Level II system can be used to conservatively estimate the surface roughness of metropolitan areas from highaltitude photographs. For applications requiring greater resolution, Level III land use and land cover data may be used. The U.S. Geological Survey has not published Level III land use and land cover maps but maps can be made by geographic sampling if resources are available to the user.

Table 27 lists the roughness lengths specified in boundary conditions for recent experiments in
TABLE 25.--Roughness lengths summarized in centimeters for USGS Level II land use and land cover classes

\begin{tabular}{|c|c|c|c|c|c|}
\hline Classes & $\begin{array}{l}\text { No. } \\
\text { of } \\
\text { plots }\end{array}$ & $\underset{z_{v}}{\text { Median }}$ & $\underset{z=}{\text { Mean }}$ & Range & $\begin{array}{l}\text { Stand- } \\
\text { ard } \\
\text { devia- } \\
\text { tion }\end{array}$ \\
\hline (11) Residential & 157 & 88 & 100 & 8 to 1022 & 94 \\
\hline $\begin{array}{l}\text { (12) Commercial } \\
\& \text { Services }\end{array}$ & 49 & 107 & 181 & 5 to 1468 & 265 \\
\hline (13) Industrial & 33 & 36 & 52 & 8 to 229 & 51 \\
\hline $\begin{array}{l}\text { (15) Transportation, } \\
\text { Communications, } \\
\text { \& Utilities }\end{array}$ & 33 & 29 & 47 & 4 to 557 & 96 \\
\hline (16) Institutional & 12 & 62 & 130 & 14 to 497 & 139 \\
\hline (51-54) Water & 12 & 1 & 1 & 1 to & 0.4 \\
\hline (41-43) Forest Land & 28 & 106 & 117 & 8 to 322 & 78 \\
\hline
\end{tabular}

TABLE 26.-Roughness lengths summarized in centimeters for Baltimore Level III land use and land cover classes and the $C B D^{1}$

[See table 14 for category descriptions]

\begin{tabular}{|c|c|c|c|c|c|}
\hline Class & $\begin{array}{c}\text { No. } \\
\text { of } \\
\text { plots }\end{array}$ & $\underset{z_{\theta}}{\text { Median }}$ & $\underset{z_{n}}{\operatorname{Mean}}$ & & Range \\
\hline OPEN & 32 & 8 & 7 & 1 & to \\
\hline CLD & 5 & 11 & 11 & 7 & to \\
\hline ILD & 39 & 28 & 28 & 8 & to \\
\hline RLD2 & 6 & 39 & 38 & 29 & to \\
\hline WLD & 13 & 49 & 48 & 30 & to \\
\hline RMD2 & 43 & 71 & 73 & 30 & to 118 \\
\hline RMD2W & 28 & 73 & 76 & 38 & to 139 \\
\hline CMD & 28 & 78 & 87 & 10 & to 218 \\
\hline IMD & 15 & 82 & 78 & 39 & to 118 \\
\hline RMD2W & 19 & 86 & 120 & 51 & to 350 \\
\hline RMD3 & 21 & 114 & 113 & 43 & to 221 \\
\hline WHD & 13 & 115 & 116 & 60 & to 160 \\
\hline IHD & 10 & 126 & 162 & 35 & to 557 \\
\hline RMD4 & 9 & 151 & 147 & 89 & to 213 \\
\hline INST & 12 & 155 & 162 & 20 & to 413 \\
\hline RMD3W & 9 & 185 & 178 & 96 & to 312 \\
\hline WHD & 9 & 260 & 245 & 185 & to 322 \\
\hline HR & 16 & 322 & 481 & 128 & to 1468 \\
\hline CBD & $\left({ }^{1}\right)$ & 673 & 850 & 51 & to 2118 \\
\hline
\end{tabular}

1 The CBD was sampled as one continuous unit.

urban atmospheric simulation modeling. About half of the models cited were assigned a single roughness length to represent the entire city. Sensitivity analysis of numerical simulation models of the surface climate has shown, however, that small aerodynamic roughness differences may have significant effects on turbulent transfer of energy away from the surface-air interface (Myrup, 1969; Nicholas, 1974). The generalizations in table 27 exist partly because of the paucity of actual urban wind profile measurements (table 1). Other modeling efforts cited in table 27 show some attempt to use a range of hypothetical urban roughness lengths, for example, 2 to $300 \mathrm{~cm}$. These stepped values, however, are generally limited to use for sensitivity testing 
TABLE 27.-Some recent climatological models using roughness lengths in centimeters

\begin{tabular}{|c|c|c|}
\hline Author & Model & $z_{0}$ \\
\hline $\begin{array}{l}\text { Bornstein } \\
\quad(1972)\end{array}$ & $\begin{array}{l}\text { A two-layer atmospheric } \\
\text { model for simulating } \\
\text { nighttime conditions over } \\
\text { a warm, aerodynamically } \\
\text { rough city. }\end{array}$ & $\begin{aligned} & \\
& 300 \\
& \because 50\end{aligned}$ \\
\hline $\begin{array}{l}\text { Davis \& Pearson } \\
\quad(1970)\end{array}$ & $\begin{array}{l}\text { Physical similarity model of } \\
\text { Ft. Wayne, Ind. }\end{array}$ & 200 \\
\hline $\begin{array}{l}\text { Atwater } \\
\quad(1972)\end{array}$ & $\begin{array}{l}\text { Numerical model of urban } \\
\text { temperature response to } \\
\text { changes in physical sur- } \\
\text { face, pollutant strength }\end{array}$ & $\begin{array}{rl}1 & 100 \\
2 & 1\end{array}$ \\
\hline $\begin{array}{l}\text { Pandolfo \& others } \\
\text { (1971) }\end{array}$ & $\begin{array}{l}\text { Numerical model of trans- } \\
\text { port and diffusion }\end{array}$ & $\begin{array}{rl}{ }^{1} 100 \\
{ }^{2} & 1\end{array}$ \\
\hline Myrup & $\begin{array}{l}\text { Analog model of the urban } \\
\text { heat island }\end{array}$ & $1-457$ \\
\hline $\begin{array}{l}\text { Outcalt } \\
\qquad(1972 a)\end{array}$ & $\begin{array}{l}\text { Digital model of the urban } \\
\text { heat island modified from } \\
\text { Myrup (1969) }\end{array}$ & $2-300$ \\
\hline $\begin{array}{l}\text { Miller \& others } \\
\quad(1972)\end{array}$ & $\begin{array}{l}\text { A scrutiny of the models of } \\
\text { Myrup (1969) and Out- } \\
\text { calt (1972a) }\end{array}$ & $\begin{aligned} & \\
& 250 \\
- & 10\end{aligned}$ \\
\hline $\begin{array}{l}\text { Myrup \& Morgan } \\
(1972)\end{array}$ & $\begin{array}{l}\text { Numerical model of urban } \\
\text { erergy balance at Sacra- } \\
\text { mento, Calif. }\end{array}$ & (अ) \\
\hline Tag & $\begin{array}{l}\text { Model of urban surface } \\
\text { temperature }\end{array}$ & $1-300$ \\
\hline $\begin{array}{l}\text { McEIroy } \\
(1972)\end{array}$ & $\begin{array}{l}\text { Effect of alternative land } \\
\text { use strategies on the } \\
\text { thermal structure of air } \\
\text { over cities }\end{array}$ & $5-300$ \\
\hline $\begin{array}{l}\text { Chaundry and } \\
\text { Cermak } \\
(1971)\end{array}$ & Wind tunnel model & $\left({ }^{4}\right)$ \\
\hline
\end{tabular}

rather than for assigning specific values to particular land use and land cover categories. On the other hand, Myrup and Morgan (1972) estimate surface roughness for a unique 15-category land use and land cover classification system derived from 56 urban site samples in Sacramento, Calif. This work is the only urban climate model using surface roughness estimates derived from an interpretation of land use and land cover classes.

The summaries in tables 26 and 27 provide the user with information regarding the principal statistical characteristics of roughness data determined in this paper. Other properties of the data may also be assessed. Skewness, for example, can be determined in part from the difference between the mean and median surface roughness values of a given land class. Knowledge of the sample size (in this case, the number of plots) also suggests the degree of confidence that may be placed in a given estimate.

Knowledge obtained from a given land use and land cover map can be applied directly to urban

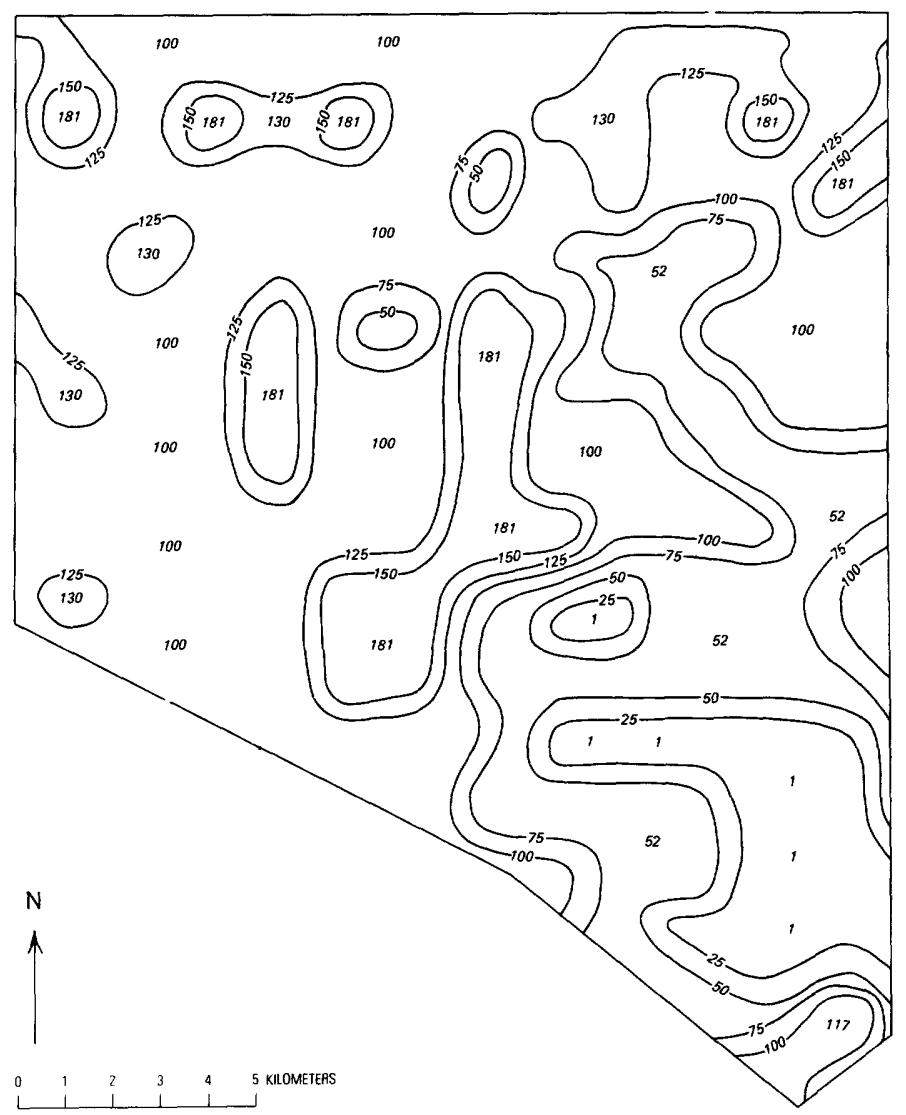

Figure 14.-Contours on surface roughness in Baltimore, Md., simulated from USGS Level II land use and land cover data. Values are mean roughness lengths, in centimeters.

climate problems by using this information as a surrogate for aerodynamic roughness. This application is demonstrated for Baltimore by using land use and land cover maps at two scales. Figure 14 shows the estimated surface roughness derived from the USGS Level II land use and land cover map in figure 9. This mapped estimate was based on 200 systematically distributed point samples with data assigned to each point from the mean roughness values listed in table 26 for each particular land use and land cover category. This estimate is conservative because the level of generalization of the Level II system is relatively high. Figure 15 shows the estimated surface roughness at the Level III scale. The planning map in figure 3 was used as a base to identify the land use and land cover categories at sample locations. Sample values were assigned from table 26, and then the distribution was mapped. Greatly improved resolution is achieved by the Level III estimate, yet the major trends are visible in the Level II estimate in figure 14. 


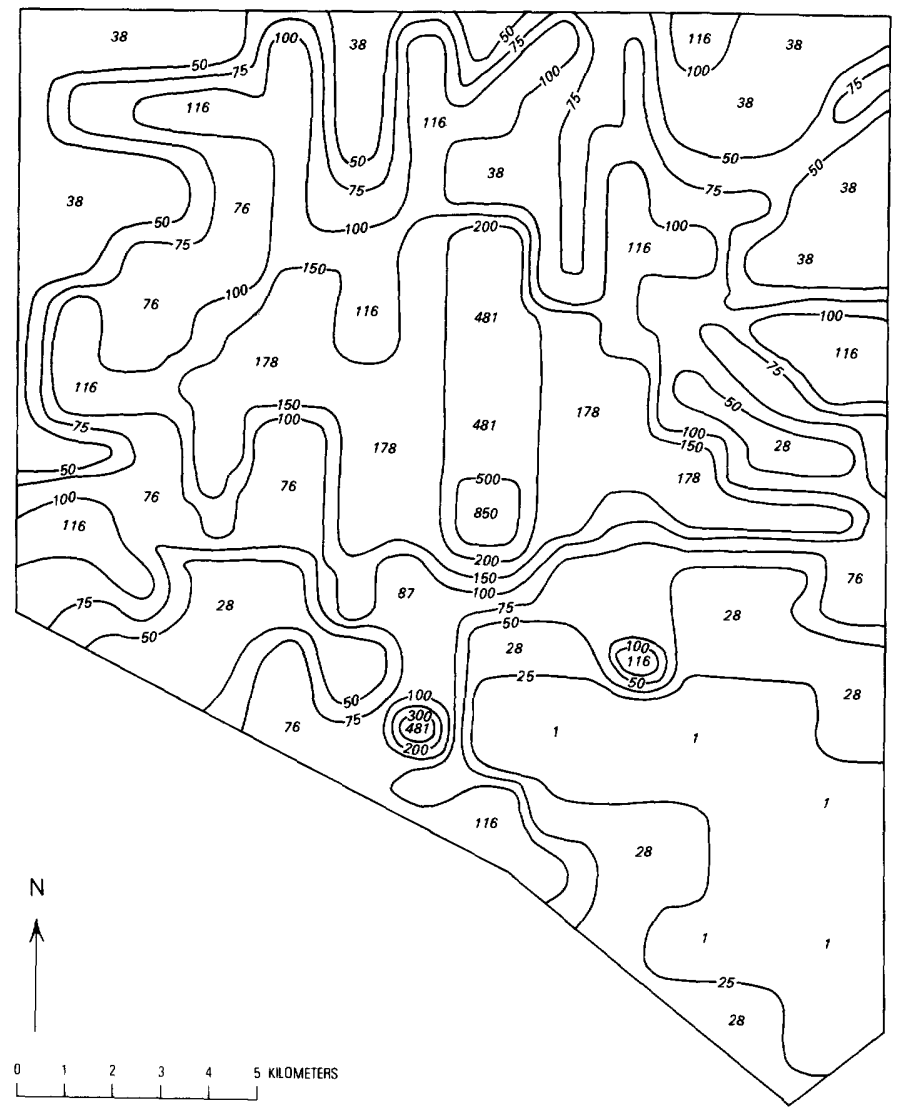

Figure 15.-Contours on surface roughness in Baltimore, Md., simulated from Baltimore Level III land use and land cover da sa. Values are mean roughness lengths, in centimeters.

This method of relating land use and land cover characteristics to aerodynamic roughness shows that acquiring indirect estimates of environmental parameters from sources such as high-altitude photographs can provide a method for rapidly producing a reliable spatial distribution of these parameters. Although subject to verification by careful ground measurements, the use of surrogates such as descriptions of land use and land cover for the measurement of environmental parameters can improve the accuracy of the specification of those boundary conditions important to climatic simulation modeling and ultimately to urban growth.

\section{REFERENCES CITED}

Abrams, Charles, 1965, The uses of land in cities: Scientific American, v. 213, no. 3, p. 151-160.

Alexander, R. H., and Lewis, J. E., 1972, Geographic Applications Program climatology sub-project: U.S. Geological Survey unpublished report.

Anderson, G. E., 1971, Mesoscale influences on wind fields: Journal of Applied Meteorology, v. 10, no. 3, p. 377386.
Anderson, J. R., Hardy, E. E., and Roach, J. T., 1972, A land-use classification system for use with remote-sensor data: U.S. Geological Survey Circular 671, 16 p.

Anderson, J. R., Hardy, E. E., Roach, J. T., and Witmer, R. E., 1976, A land use and land cover classification system for use with remote sensor data: U.S. Geological Survey Professional Paper 964, $28 \mathrm{p}$.

Appleby, J. F., and Fujikado, L. A., 1960, Special cases of simulating the energy budget of the Earth/air interface: U.S. Army Electronic Proving Grounds-Signal Corps, Ft. Hauchuca, Ariz., USAEPG-SG 970-30.

Atwater, M. A., 1972, Thermal changes induced by urbanization and pollutants: American Meteorology Society, Conference on Urban Environment and Second Conference on Biometeorology, Philadelphia, Pa., October 31November 2, 1972 Proceedings, p. 153-158.

Bornstein, R. D., 1972, Two dimensional non-steady numerical simulations of nighttime flow of a stable boundary layer over a rough warm city: American Meteorology Society, Conference on Urban Environment and Second Conference on Biometeorology, Philadelphia, Pa., October 31-November 2, 1972 Proceedings, p. 89-98.

Brunt, David, 1934, Physical and dynamical meteorology: Cambridge, Mass., Cambridge University Press.

Chaundry, F. H., and Cermak J. E., 1971, Simulation of flow and diffusion over an urban complex: American Meteorological Society, Conference on Air Pollution Meteorology, Raleigh, N. C., April 1971 Proceedings, p. 126-131.

City of Baltimore, 1971, Zoning ordinance of Baltimore city: Baltimore, Md., Ordinance 1051 Amended by Ordinance 1201.

Davenport, A. G., 1967, Instrumentation and measurements of wind speed spectra in a city: Canadian Conference on Microclimatology, Toronto, Ontario, 1st Proceedings.

Davis, M. L., and Pearson, J. E., 1970, Modeling urban atmospheric temperature profiles: Atmospheric Enivronment, v. 4 , no. 3 , p. $277-288$.

Deland, R. J., and Binowski, F. S., 1966, Comparison of wind at 500 feet over Minneapolis and Louisville with geostrophic wind: Journal of Air Pollution Control Association, v. 16 , no. 8 , p. 407-411.

Dixon, W. J., and Massey, F. J., 1969, Introduction to statistical analysis (3d ed.) : New York, McGraw-Hill.

Downie, N. M., and Heath, R. W., 1959, Basic statistical methods: New York, Harper and Row.

Dudnik, E. E., 1971, SYMAP user's reference manual: Chicago, University of Illinois, Department of Architecture, Report no. 71-18.

Estoque, M. A., 1963, A numerical model of the atmospheric boundary layer: Journal of Geophysical Research, v. 68, no. 4, p. 1103-1113.

Graham, I. R., 1968, An analysis of turbulence statistics at Fort Wayne, Indiana: Journal of Applied Meteorology, v. 7 , no. 1, p. 90-93.

Halstead, M. H, Richman., R. L., Covey, W., and Merryman, J. E., 1957, A preliminary report on the design of a computer for micrometeorology: Journal of Applied Meteorology, v. 14 , no. 4 , p. $308-325$.

Jones, P. M., de Larrinaga, M.A.B., and Wilson, C. B., 1970, Some measurements of the wind velocity profile in the first 1,000 feet, in Urban climates: World Meteorological Organization Technical Note no. 108, WMO-no. 254, technical publication 141, Geneva, $390 \mathrm{p}$. 
King, J. L., 1969, Statistical analysis in geography: Englewood Cliffs, N. J., Prentice-Hall.

Kung, E. C., 1961, Derivation of roughness parameters from wind profile data above all vegetation: Madison, Wis., University of Wisconsin, Department of Meteorology, Annual Report.

Kutzback, J. E., 1961, Investigations of the modification of wind profiles by artificially controlled surface roughness: Madison, Wis., University of Wisconsin, Department of Meteorology, Annual Report.

Landsberg, H. E., 1957, Review of climatology, 1951-1955: Meteorology Research Reviews, v. 3, no. 12, p. 1-43.

- 1973, Climate of the urban biosphere: International Journal of Biometeorology: v. 5, p. 71-83.

Leonard, R. E., and Federer, C. A., 1973, Estimated and measured roughness parameters for a pine forest: Journal of Applied Meteorology, v. 12, no. 2, p. 302-307.

Lettau, H. H., 1951, Theory of surface temperature and heat-transfer oscillations near a level ground surface: Transactions of the American Geophysical Union, v. 32, no. 2, p. 189-200.

1967, Problems of micrometeorological measurements: (on degree of control in out-of-doors experiments), in Bradley, E. F. and Denmead, O. T., eds., The collection and processing of field data: New York, Interscience, p. $3-40$.

1969 , Note on aerodynamic roughness-parameter estimation on the basis of roughness-element description: Journal of Applied Meteorology, v. 8, no. 5, p. 828832.

1970, Physical and meteorological basis for mathematical models of urban diffusion processes: U.S. Environmental Protection Agency, Symposium on MultipleSource Urban Diffusion Models, Research Triangle Park, N. C., October 27-30, 1969 Proceedings, p. 2-1-2-6.

Lettau, H. H., and Lettau, K., 1969, Shortwave radation climatology: Tellus, v. 21, no. 2, p. 208-222.

- 1974, Regional climatology of tundra and boreal forests in Canada: American Meteorology Society, 24th Alaska Science Conference, Fairbanks, Alaska, p. 209-221.

Maisel, T. N., 1971, Early micrometeorological changes caused by urbanization: College Park, Md., University of Maryland, Institute for Fluid Dynamics and Applied Mathematics, Meteorology Programs, M.S. Thesis. Available from University Microfilms.

McElroy, J. L., 1972, Effects of alternate land use strategies on the structure of the nocturnal urban boundary layer: American Meteorology Society, Conference on Urban Environment and Second Conference on Biometerology, Philadelphia, Pa., October 31-November 2, 1972 Proceedings, p. $185-190$.

Miller, E. L., Johnston, R. E., and Lowry, W. P., 1972, The case of the muddled meteoromodel: American Meteorology Society, Conference on Urban Environment and Second Conference on Biometeorology, Philadelphia, Pa., October 31-November 2, 1972 Proceedings, p. 77-82.

Monteith, J. L., 1973, Principles of environmental physics: London, Edward Arnold.

Munn, R. E., 1966, Descriptive micrometeorology: New York, Academic Press.

Munro, D. S., and Oke, T. R., 1973, Estimating wind profile parameters for tall dense crops: Agricultural Meteorology, v. 11, no. 2, p. 223-228.
Myrup, L. O., 1969, A numerical model of the urban heat island: Journal of Applied Meteorology, v. 8, no. 6, p. 908-918.

Myrup, L. O., and Morgan, D. L., 1972, Numerical model of the urban atmosphere, v. 1, The city-surface interface: Davis, Calif., University of California, Control in Atmospheric Science, no. 4.

Nicholas, F. W., 1974, Parameterization of the urban fabrica study of surface roughness with application to Baltimore, Maryland: College Park, Md., University of Maryland, Department of Geography, Ph.D. dissertation. Available from University Microfilms.

Oke, T. R., and East, Conrad, 1971, The urban boundary layer in Montreal: Boundary Layer Meteorology, v. 1, no. 4 , p. 411-437.

Outcalt, S. I., 1972a, The development and application of a simple digital surface-climate simulator: Journal of Applied Meteorology, v. 11, no. 4, p. 629-636.

$1972 \mathrm{~b}, \mathrm{~A}$ reconnaissance experiment in mapping and modeling the effect of land use on the urban thermal regiment: Journal of Applied Meteorology, v. 11, no. 8, p. 1369-1373.

Pandalfo, J. P., Atwater, M. A., and Anderson, G. E., 1971, Prediction by numerical models of transport and diffusion in an urban boundary layer: Hartford, Conn., Center for the Environment and Man.

Pease, R. W., Lewis, J. E., and Outcalt, S. I., 1976, Urban terrain climatology and remote sensing: Annals of the Association of American Geographers, v. 66, no. 4, p. 557-569.

Plate, E. J., 1971, Aerodynamic characteristics of atmospheric boundary layers: Oak Ridge, Tenn., U.S. Atomic Energy Commission, AEC Critical Review Service.

Rosenberg, N. J., 1966, Microclimate air mixing and physiological regulation of transpiration as influenced by wind shelter in an irrigated bean field: Agricultural Meteorology, v. 3, no. 2, p. 197-224.

Sellers, W. D., 1965, Physical climatology: Chicago, University of Chicago Press.

Shiotani, M., 1970, The relationship between wind profiles and stabilities of the air layer in the outskirts of the city, in Urban climates: World Meteorological Organization Technical Note no. 108, WMO-no. 254, technical publication 141, Geneva, $390 \mathrm{p}$.

Siegel, Sidney, 1956, Nonparametric statistics for the behavioral sciences: New York, McGraw-Hill.

Slade, D. H., 1968, Meteorology and atomic energy 1968: Oak Ridge, Tenn., U.S. A tomic Energy Commission.

- 1969, Wind measurements on a tall tower in rough and homogeneous terrain: Journal of Applied Meteorology, v. 8, no. 2, p. 293-297.

Snedecor, G. W., and Cochran, W. G., 1967, Statistical methods (16th ed.): Ames, Iowa, Iowa State University Press.

Stearns, C. R., and Lettau, H. H., 1963, Two wind-profile measurement experiments in airflow over the ice of Lake Mendota: Madison, Wis., University of Wisconsin, Department of Meteorology, Annual Report.

Szeicz, G., Endrodi, Gavriella, and Tajchman, S., 1969, Aerodynamic and surface factors in evaporation: Water Resources Research, v. 5, no. 2, p. 380-394.

Tag, P. M., 1969, Atmospheric modification by surface in- : fluences, p.t. I, Surface temperatures in an urban en- 
vironment: University Park, Pa., Pennsylvania State University, Department of Meteorology, Report no. 15.

Tanner, C. B., and Pelton, W. L., 1960, Potential evapotranspiration estimates by the approximate energy balance method of Penman: Journal of Geophysical Research, v. 65 , no. 10 , p. $3391-3413$.

U.S. Geological Survey, 1977, U. S. Geological Survey yearbook fiscal year 1977: Available from U.S. Government Printing Office, Washington, D.C., stock no. 024-00103042-0, $229 \mathrm{p}$.

Wallace, D. W., McHarg, I. L., Roberts, W. H., and Dodd, T. A., 1970, MetroCenter/Baltimore technical study: Baltimore, Department of Planning.
Wray, J. R., 1970, The Census Cities project and atlas of urban and regional change: NASA Manned Spacecraft Center, 3rd Annual Earth Resources Program Review, Houston, Tex., December 1970 Proceedings, v. I, sec. 2, p. 1-16.

1973, Land use map, 1970, Washington urban area, D.C., Md., and Va.: U.S. Geological Survey Map I-858A, scale $1: 100,000$.

Yamamoto, G., and Shimanuki, A., 1970, Profiles of wind and temperature in the lowest 250 meters in Tokyo, in Urban climates: World Meteorological Organization Technical Note No. 108, WMO-No. 254, technical publication 141, Geneva, 390 p. 